
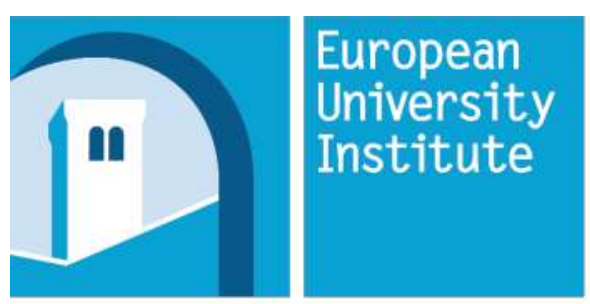

DEPARTMENT

OF

ECONOMICS
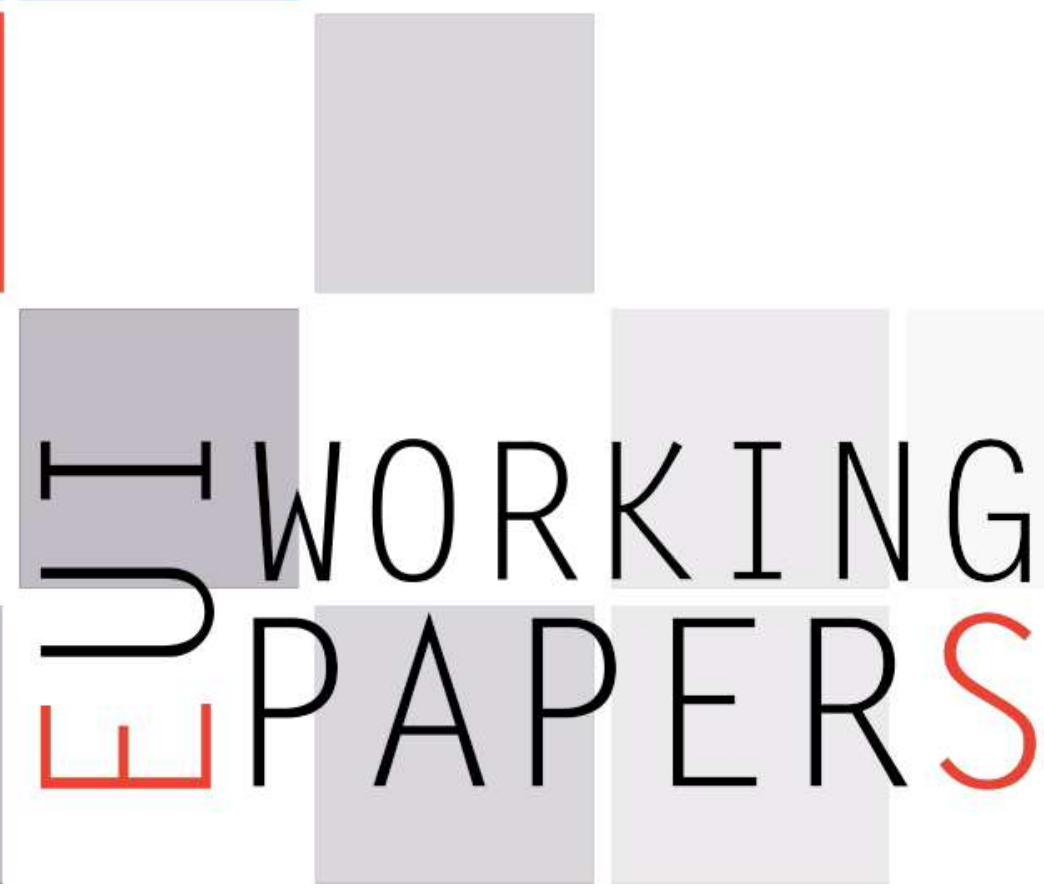

ECO 2016/04

Department of Economics

Sovereign Debt Issuance and Selective Default 

European University Institute

Department of Economics

Sovereign Debt Issuance and Selective Default

Wojtek Paczos and Kirill Shakhnov

EUI Working Paper ECO 2016/04 
This text may be downloaded for personal research purposes only. Any additional reproduction for other purposes, whether in hard copy or electronically, requires the consent of the author(s), editor(s). If cited or quoted, reference should be made to the full name of the author(s), editor(s), the title, the working paper or other series, the year, and the publisher.

ISSN 1725-6704

(C) Wojtek Paczos, Kirill Shakhnov, 2016

Printed in Italy

European University Institute

Badia Fiesolana

I - 50014 San Domenico di Fiesole (FI)

Italy

www.eui.eu

cadmus.eui.eu 


\title{
Sovereign Debt Issuance And Selective Default*
}

\author{
Wojtek Paczos ${ }^{\dagger} \quad$ Kirill Shakhnov ${ }^{\ddagger}$
}

First Version: May 2013

This Version: December 2015

\begin{abstract}
We propose a novel theory to explain why sovereigns borrow on both domestic and international markets and why defaults are mostly selective (on either domestic or foreign investors). Domestic debt issuance can only smooth tax distortion shocks, whereas foreign debt can also smooth productivity shocks. If the correlation of these shocks is sufficiently low, the sovereign borrows on both markets to avoid excess consumption volatility. Defaults on both types of investors arise in equilibrium due to market incompleteness and the government's limited commitment. The model matches business cycle moments and frequencies of different types of defaults in emerging economies and we show our hypothesis is confirmed by the data. We also find, that secondary markets are not a sufficient condition to avoid sovereign defaults. The outcome of the trade in bonds on secondary markets depends on how well each group of investors can coordinate their actions.
\end{abstract}

Keywords: sovereign debt, selective default, debt composition, secondary markets

JEL Classification: E43, F34, G15, H63

${ }^{*}$ We would like to thank Manuel Amador, Fernando Broner, Russell Cooper, Giancarlo Corsetti, Antonia Diaz, Juan Dolado, Tim Kehoe, Sandra Lizarazo, Frank Portier and Jaume Ventura for many useful comments and suggestions. We are especially grateful to Árpád Ábrahám, Evi Pappa and Ramon Marimon for all their advice and constant support. The paper has benefited from discussions with seminar participants at Cardiff University, EUI Florence, European Central Bank, ETH Zurich, University of Konstanz, UPF Barcelona, Vienna University of Economics and Business; the Annual Congress of the European Economic Association at the University of Mannheim, the Meeting of the Econometric Society at the University of Minnesota, the Money, Macro and Finance RG Annual Conference in Cardiff, the RCEA Conference in Economics and Finance in Rimini, the SCE Computing in Economics and Finance conference in Oslo, UniCredit \& Universities Young Economists Conference in Belgrade and the Workshop on Dynamic Macroeconomics in Vigo.

${ }^{\dagger}$ Cardiff University and European University Institute, wojciech.paczos@eui.eu

${ }^{\ddagger}$ Einaudi Institute for Economics and Finance, kirill.shakhnov@eief.it 


\section{Introduction}

Humanity has witnessed sovereign debt crises for hundreds of years. The first recorded instance of sovereign default dates back to 377 B.C. in ancient Greece. Sovereign default has been studied extensively in the literature. However, the focus has mainly been on default on external debt, while the study of domestic defaults has been neglected. Reinhart and Rogoff (2011b) have documented and categorized all default events in the last 210 years. Based on their observations, there have been at least 58 de jure defaults on domestic public debt. This is certainly an underestimate, due to the difficulty of detecting pure domestic defaults. ${ }^{1}$ Also, out of 267 defaults in this period, only 17 times did the government default simultaneously on both domestic and foreign debt.

In this paper, we address the open question of why governments usually default selectively on either foreign or domestic debt. We do so by providing a novel theory of domestic debt and default, where domestic debt is issued to smooth tax distortions, and combining it with the well established literature on foreign debt and default. We present a two-period model to deliver the economic intuition, and a calibrated quantitative model to replicate data moments. We show that our theory is empirically plausible, as it is able to match frequencies of different types of default and debt compositions. To the best of our knowledge, this is the first contribution that is able to replicate two stylized facts: that defaults happen mostly in a selective fashion, and that the composition of bondholders matters for interest rates and the volume of total public debt. The two-period version of the model is the starting point for an additional discussion of the role of secondary markets in solving sovereign default problems. Our analysis questions the efficiency role associated with secondary markets.

We build an incomplete markets model in which the government has limited commitment. The government has to cover its expenditures and has three means of financing them: it issues one-period defaultable bonds on an international and a domestic market, and it collects taxes. Tax collection is costly because taxes are distortionary. The economy is subject to two shocks: an output shock and a tax distortion shock. While the output shock provides incentives for the government to borrow on international markets, the tax distortion shock creates a wedge between domestic borrowing and taxation. This breaks Ricardian equivalence in our endowment economy, and draws a distinction between tax-financed and debt-financed expenditure policies. In this we provide a simple theory of domestic debt issuance.

Foreign debt can be used to smooth out both shocks, which makes it a more valuable instrument. However, if the correlation of the two processes is sufficiently low, then using only one instrument to smooth two shocks would result in households' consumption being too volatile. Therefore, the government engages in borrowing on both markets. When the government has outstanding debts on both markets it faces two trade-offs: one between foreign

\footnotetext{
${ }^{1}$ For example, the large-scale 1989 pure domestic default is relatively unknown outside Argentina. The most well know domestic default happened in Russia 1998, which was one of the largest local currency debt defaults (US \$39 billion). This number does not include de facto default through inflation, the nationalization of pensions and other forms.
} 
repayment and default, and another between domestic repayment and default.

The mechanism of foreign default is similar to that in Eaton and Gersovitz (1981) and Arellano (2008). A benevolent government accumulates defaultable foreign debt in order to smooth residents' consumption over the business cycle. Interest rates reflect default probabilities, which are endogenous to the borrower's incentives to default. The government decides each period whether to transfer resources away from the economy as a repayment of debt to foreign investors or to keep resources at home and suffer default penalties. When output is low, ceteris paribus, it is more costly for a risk averse borrower to respect the contract. Default occurs along the equilibrium path after a long enough sequence of negative output shocks. These contributions gave rise to a large literature, which has nonetheless not yet considered domestic debt and default in an open economy setting.

While the mechanisms and trade-offs behind foreign default are clear, the domestic default literature is still at an early stage. There are two recent contributions that adhere to the benevolent government assumption and study domestic default in a Ramsey setting. D'Erasmo and Mendoza (2013) propose a heterogeneous agent model in which a utilitarian government relies on lump-sum taxes and defaultable bonds to finance stochastic governments expenditures. Default has a redistributive aspect, because it hurts mostly the rich, while repayment by taxation hurts mostly the poor. Pouzo and Presno (2014), on the other hand, consider a model in which the government relies on distortionary labor income taxes and defaultable bonds to finance its stochastic expenditures. The government might default to mitigate these distortions. The second crucial trade-off in our model, the one behind domestic debt and default, is similar to their mechanism. Both contributions, however, are closed-economy models that do not consider borrowing on international markets.

Both repayment and default on domestic debt are transfers of resources within the economy. In a case of default on domestic debt, the government suffers default penalties similar to the penalties imposed after foreign default. When the government decides to repay, it needs to finance this repayment by collecting taxes. When distortions from taxation are high, the government prefers to issue debt rather than collect taxes, hoping that in the future tax collection will be less distortionary, giving it the ability to repay the debt at a lower cost. The government thus issues domestic debt up to an endogenous debt limit, and if the possibility of repayment through non-distortionary taxes does not arrive it has no other choice than to default.

Vasishtha (2010) and Erce (2012) study the selective nature of sovereign default with foreign and domestic investors. The former generates domestic debt issuance through disutility of taxation, but in equilibrium foreign default never happens. In the latter, both domestic and foreign debt levels are exogenously predetermined. Our analysis shows that incorporating two shocks, to output and to taxation, is crucial to generating equilibria with both types of selective default, and that the feedback loop from selective default to debt issuance should not be neglected. In our paper, both domestic and foreign debt issuance and selective default are optimal decisions of the government. In addition, Cooper et al. (2008) study how the distribution of debt among domestic and foreign 
investors influences the government's incentives to default. They find conditions (government expenditure and the fraction of debt held by foreign investors being high enough) under which the government has incentives to default, but the underlying composition of debt is given exogenously. In this paper, we derive endogenous fractions of public debt held by domestic and foreign investors.

The main contributions of this paper are the new theory of selective sovereign defaults and a quantitative framework to study sovereign debt issuance and debt composition. But our analysis also has also some other, quite novel implications. After the Great Recession, secondary sovereign debt markets attracted increasing interest among economists. Based on the two-period version of our model, we analyze the role of secondary markets in solving the problem of sovereign risk. Broner et al. (2010) show that, even in the absence of default penalties, sovereign risk does not prevent governments from borrowing on international markets if foreign creditors can resell their assets to domestic investors on secondary markets under the assumption that tax collection is costless. Instead, we assume that taxation is costly, and show that the result of the trade depends on how well each group of investors can coordinate their actions. In particular, without any coordination, trade on secondary markets generates a possible welfare loss, as it incentivizes the government to default on all its debt, instead of only foreign debt. We also prove that whenever secondary markets fail to reduce the default problem, debt haircuts can play a useful role, and vice versa.

The remainder of the paper is organized as follows. In the next section we summarize empirical facts on domestic and foreign public debt holdings and selective defaults. Section 3 studies equilibrium in a two-period model and shows intuitively the main trade-offs. Section 4 presents an infinite-horizon version of the model and the results of a calibration exercise. Section 5 analyzes the role of secondary markets and haircuts. The last section concludes.

\section{Facts}

The goal of this section is to establish three stylized facts that motivate our analysis. First, that sovereign defaults happen mostly in a selective fashion; second, that governments have a number of tools to discriminate among different types of bondholders; and third, that the composition of bondholders matters. In this section we review some empirical studies of selective sovereign defaults and the composition of bondholders, and augment them with our findings.

Before we begin our discussion, we set the scene with some definitions. There are three different ways to draw the distinction between domestic and foreign debt. According to the legal definition, domestic debt is any debt issued according to domestic law, regardless of its currency, and regardless of who holds it. According to the economic definition, domestic debt is held by residents, regardless of the currency and the law under which it was issued. Finally, according to the currency definition, domestic debt is the debt denominated in home currency, regardless 
of law and the residency of bond holders. The second definition creates clear differential incentives for the sovereign to default. For this reason, throughout the model, we adopt the economic definition.

An important point to raise is that these three definitions do not necessarily overlap. However, Reinhart and Rogoff (2011a) claim that: "The overwhelming majority of external public debt, debt under the legal jurisdiction of foreign governments, has been denominated in foreign currency and held by foreign residents". This was certainly true before the wave of capital flow liberalizations starting in the 1980s. After this, the mapping between the legal and the economic definitions is less ideal. ${ }^{2}$ Still, we observe selective sovereign defaults both before and after the wave of capital flow liberalizations.

For our stylized facts and in our calibration we rely on three sources of data. Merler and Pisani-Ferry (2012) provide the breakdown of the public debt by the residence of holders for ten industrialized economies between 1990 and 2012. For the developing economies we rely on the dataset compiled by Panizza (2008), which covers the data of up to 130 countries between 1990 and 2007. Data for developing economies is however obtained using the legal definition. Our third source is the dataset on crises and defaults provided by Reinhart and Rogoff (2011b), which covers up to 70 countries between 1800 and 2010. The legal definition of debt is also used for the default data. In what follows we present three empirical facts that motivate and guide our theoretical analysis.

1. Sovereign defaults usually happen in a selective fashion. The database collected by Reinhart and Rogoff (2011b) reveals interesting features of sovereign default episodes between 1800 and 2010. First, domestic debt, usually neglected in the theoretical literature on sovereign risk, plays an important role in the build-up, during and after sovereign defaults on foreign holdings. This argument is extensively developed in Reinhart and Rogoff (2011a). Second, sovereign defaults happen on both domestic and foreign debt holdings, usually in a selective fashion. Whereas foreign defaults are common, domestic defaults are hardly rare. Out of 267 episodes of sovereign debt crisis identified across 70 countries in the last 210 years, 205 were pure foreign, 26 were pure domestic, and 36 featured government default on both domestic and foreign debt. Only 17 times did the default on home and foreign debt happen within the same year. In Figure 1 we plot the fraction of sovereign borrowers that were in foreign, domestic or total default in a given year between 1800 and 2010. These findings suggest that the assumption that sovereigns can default selectively fits reality better than the two alternative assumptions commonly used in the literature: that domestic debt is always senior and so only foreign debt is defaulted on, or that defaults can only be non-discriminatory.

\footnotetext{
${ }^{2}$ A notable example here is the Mexican crisis of 1994. Short-term securities called tesobonos were dollar-denominated (foreign debt according to the currency definition), issued according to Mexican law (domestic debt according to the legal definition) and held by investors both in the US and Mexico (partly domestic and partly foreign debt according to the economic definition). Also, at that time, there were no means of tracing the final creditor either by nationality or by residence. Therefore, a default on tesobonos obligations could not have been classified either as domestic or as foreign selective default. Luckily, Mexico did not default in 1994 .
} 
Figure 1: Fraction of countries in different types of default

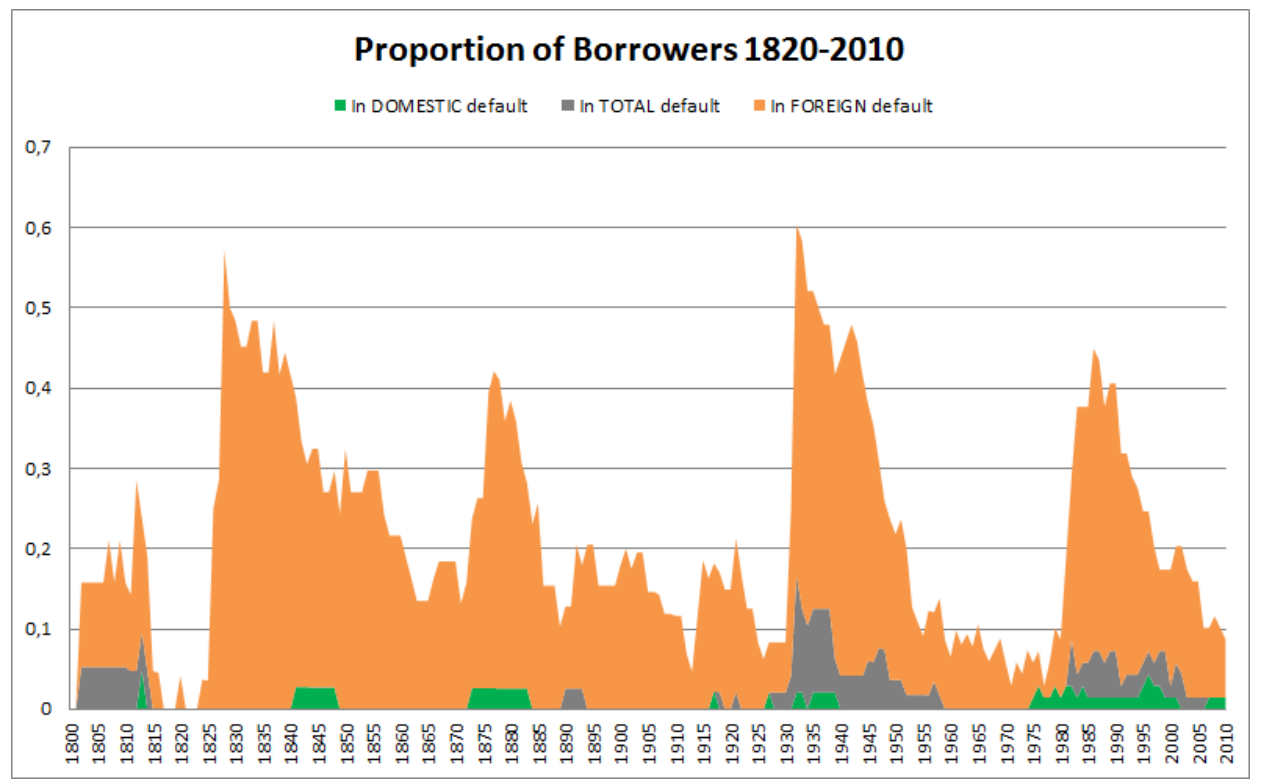

Source: Own calculations based on Reinhart and Rogoff (2011b)

2. Governments have a number of tools to discriminate among types of bondholders. How can the government default on foreign investors while repaying domestic investors or vice versa? The assumption that the two types of bondholders are indistinguishable, and therefore sovereigns can only default on total debt outstanding, underestimates the creativity of governments.

Among the tools that governments use to discriminate against particular types of bondholders, the most popular are capital controls, exchange controls and freezes on deposits. In 1990 Brazil defaulted on its domestic debt but kept servicing its foreign debt. All foreign exchange transactions were directed through the central bank and a multiple exchange rate regime was introduced as well as a freeze on local currency deposits.

In 1998 Russia defaulted on both foreign and local currency debt, imposing capital and exchange rate controls. However, in subsequent years Russia "undefaulted" on its foreign obligations and kept servicing debts to foreign investors. Moreover, bonds held by domestic companies were also repaid, so Russia effectively defaulted only on domestic households' holdings of public debt. Default was accompanied by both foreign and local currency deposit freezes.

Argentina's 2001 default is often considered as a model case of foreign default. ${ }^{3}$ In fact, this episode is cataloged

\footnotetext{
${ }^{3}$ Many sovereign default models are calibrated to mimic salient features of this default (e.g. Arellano (2008)).
} 
as a total default. First, all resident-held bonds, both domestic and foreign currency denominated, were converted to government-guaranteed loans, which were all later converted to pesos at a much lower rate than the market exchange rate. Also, $60 \%$ of the debt defaulted on in December 2001 was held by Argentines.

Recent examples of what could be considered pure foreign default (in peaceful times) include: Bolivia in 1989 (most domestic debt was repurchased a year before default), Pakistan in 1999 (which stopped payments on outstanding obligations to creditors in the UK, Europe and the US and put a freeze on foreign currency deposits mostly owned by non-residents) and most probably Cyprus in 2013 (freeze and partial expropriation of deposits exceeding $€ 100,000$, which were mostly owned by non-residents).

3. The composition of bondholders matters. Empirical work on the composition of bondholders is growing. We draw on this literature, particularly on Andritzky (2012) and Dell'Erba et al. (2013), to show that the composition of investors is correlated with interest rates and the total level of debt to GDP. Dell'Erba et al. (2013) find that there is a significant correlation between spreads and debt levels when the majority of the debt is denominated in foreign currency (in both emerging economies and Eurozone countries). They also document that financial crises have more profound effects on economies that rely more on foreign borrowing. Andritzky (2012) finds a strong positive correlation between the fraction of domestic debt in total debt and the total debt-to-GDP ratio, and a negative correlation between the fraction of foreign debt and spreads in advanced economies. The present paper contributes to this literature by providing a framework to study the driving forces behind debt composition and its consequences for spreads, total debt and default incentives.

\section{Two Period Model}

We begin by introducing the model in a simplified and tractable two-period version. We study an endowment economy that consists of three types of actors: domestic households, foreign investors and a benevolent government. The government can raise resources in three different ways: by issuing bonds to domestic households, by issuing bonds to foreign investors and by collecting taxes. Taxes are lump sum, but collecting taxes comes at a cost to the economy. We assume raising an amount $T$ of taxes by the government induces a loss of $T(1+\tau)$ resources to agents. This is a key element that will break Ricardian equivalence in this endowment economy and create a trade-off between taxes and domestic debt.

Domestic households are identical and risk averse. The representative household decides on her bond holdings 
to maximize lifetime utility subject to two intra-period budget constraints:

$$
\begin{aligned}
\max _{b^{h}} & \left(u\left(c_{1}\right)+\beta \mathbb{E}\left[u\left(c_{2}\right)\right]\right) \\
& \text { subject to: } \\
& y_{1}=c_{1}+T_{1}\left(1+\tau_{1}\right)+q_{h} b_{h}, \\
& y_{2}+\left(1-d_{h}\right) b_{h}=c_{2}+T_{2}\left(1+\tau_{2}\right),
\end{aligned}
$$

where $y$ is the exogenous output, $c$ is consumption, $T$ is taxes, $\tau$ is the distortion imposed by taxes, $b_{h}$ is domestic bond holdings, $q^{h}$ is the discount price of domestic bonds and $d_{h}$ is the government's decision to repay $\left(d_{h}=0\right)$ or default on $\left(d_{h}=1\right)$ domestic debt.

Foreign investors are risk neutral and have deep pockets. They borrow on international markets at risk-free rate $r$ and lend funds to the government at discount $q_{f}$ to break even in expectation:

$$
q_{f}=\frac{\mathbb{E}\left[1-d_{f}\right]}{1+r}
$$

The government has to cover expenditures only in the first period $g_{1}>0$. Government expenditures in the second period are $g_{2}=0$. This creates an incentive to borrow due to the consumption smoothing motive. In the first period, the government decides on debt issuances in the domestic and foreign markets $b_{h}$ and $b_{f}$. In the second period, the government takes repayment decisions $d_{h}$ and $d_{f}$. The government maximizes the lifetime utility of domestic households subject to two intra-period government budget constraints:

$$
\begin{array}{r}
g_{1}=q_{h} b_{h}+q_{f} b_{f}+T_{1}, \\
\left(1-d_{h}\right) b_{h}+\left(1-d_{f}\right) q_{f}=T_{2} .
\end{array}
$$

If the government decides to default, the economy will suffer proportional output penalties. After domestic default, output in the second period is reduced to

$$
y_{h d}=y_{2}\left(1-\delta_{h}\right),
$$

and after foreign default, output in the second period is reduced to

$$
y_{f d}=y_{2}\left(1-\delta_{f}\right)
$$

If the government decides to default on both markets, the economy will suffer from both output penalties.

Finally, in the second period the economy is subject to two shocks: an output shock and a tax distortion shock. 
Both processes are stochastic Markovian and assume two outcomes:

$$
\begin{gathered}
y_{2}= \begin{cases}y_{H} & \text { with prob. } \Pi_{y} \\
y_{L} & \text { with prob. } 1-\Pi_{y},\end{cases} \\
\tau_{2}= \begin{cases}\tau_{L} & \text { with prob. } \Pi_{\tau} \\
\tau_{H} & \text { with prob. } 1-\Pi_{\tau},\end{cases}
\end{gathered}
$$

where subscript $H$ stands for high and $L$ for low.

If the debts are repaid with taxes, the government imposes distortions on the economy. If they are repaid with new debt, the government might go into default. The main driving forces of the government's optimal policies are two trade-offs. The first is the trade-off between a transfer of resources away from the economy as foreign debt repayment versus a loss of resources due to foreign default penalties. The second is between imposing distortions on the economy from tax collection versus imposing a loss of resources from domestic default penalties. Unlike in cases where Ricardian equivalence holds, the timing of taxes matters here.

\subsection{Default schedule}

We solve the model by backward induction starting in the second period. Given debt issuance decisions from the first period $b_{h}$ and $b_{f}$, in the second period the government takes default decision that maximize domestic households' utility from consumption. As it is the terminal period there is no demand for government bonds in the second period, so the only source of income for the government is taxation. In the second period, four scenarios may arise: repayment, foreign default, domestic default and total default. Substituting the government's repayment decisions $\left(d_{h} \in\{0,1\}, d_{f} \in\{0,1\}\right)$ and default penalties (7), (8) into households' second-period budget constraint (3) and the government's second-period budget constraint (6), household consumption levels in each of the four scenarios are given by the following equations: (Notice that, in order to repay an amount $b_{h}$ of domestic bonds to households, the government needs to raise $b_{h}(1+\tau)$ taxes, which yields a net loss of $\tau b_{h}$ resources to the economy.)

$$
\begin{aligned}
c^{r} & =y_{2}-b_{f}\left(1+\tau_{2}\right)-b_{h} \tau_{2}, \\
c^{f d} & =y_{2}\left(1-\delta_{f}\right)-b_{h} \tau_{2}, \\
c^{h d} & =y_{2}\left(1-\delta_{h}\right)-b_{f}\left(1+\tau_{2}\right), \\
c^{t d} & =y_{2}\left(1-\delta_{h}\right)\left(1-\delta_{f}\right),
\end{aligned}
$$

where consumption superscripts stand for repayment, foreign default, home default and total default respectively.

\section{A. Foreign default schedule}


When deciding whether to default on foreign investors, the government compares household consumption under repayment and under foreign default. It is immediate to see that foreign debt will be repaid whenever:

$$
\frac{b_{f}}{y_{2}} \leq \frac{\delta_{f}}{1+\tau_{2}}
$$

where the left-hand side is the foreign debt-to-GDP ratio and the right-hand side is a number defined by parameters of the model. Whenever the inequality has the opposite sign, the government defaults on foreign debt.

Proposition 1. If taxation is costly then the government's optimal policy on the international market is characterized by the foreign default threshold (15). Whenever the debt is below this threshold, it is riskless and is always repaid. Whenever it is above the threshold, it will always be defaulted on and therefore can never be issued. If either output or tax distortions are stochastic, the default threshold is also stochastic, debt can be risky and default can arise in equilibrium.

Proof. The first part follows directly from comparing (11) and (12). For the second part, suppose that future output $y_{2}$ and tax distortions $\tau_{2}$ are known in period one. Any debt $b_{f}$ exceeding $\frac{y_{2} \delta_{f}}{1+\tau_{2}}$ will be defaulted on with certainty in period two, therefore its discount price in period one is zero. The government is only able to take out loans $b_{f} \leq \frac{y_{2} \delta_{f}}{1+\tau_{2}}$ which are repaid with certainty. Foreign default cannot arise in equilibrium. For $b_{f}$ to be in the default area with positive probability, we need at least one parameter to be stochastic.

\section{B. Domestic default schedule}

Similarly, we can define the domestic debt limit. Domestic debt will be repaid whenever:

$$
\frac{b_{h}}{y_{2}} \leq \frac{\delta^{h}}{\tau_{2}}
$$

where the left-hand side is the domestic debt-to-GDP ratio and the right-hand side is a number defined by parameters of the model. Whenever the inequality has the opposite sign, the government defaults on domestic debt. Most importantly, the denominator on the right-hand side of inequality (16) is of a different magnitude than that in (15). This is because repayment of foreign debt is a transfer of resources out from the economy, while repayment of domestic debt is only a redistribution of resources within the economy. This redistribution is costly, and these costs are captured by the parameter $\tau_{2}$. Inequality (16) allows us to prove two interesting propositions.

Proposition 2. If taxation is costless and home default induces small positive costs to the economy, then any level of domestic debt is repaid.

This is the result of Broner et al. (2010), where taxes are assumed to be lump sum and default on domestic agents induces redistribution costs, which are endogenously derived (here captured by the parameter $\delta_{h}$ ). This result has powerful consequences. For example, if any level of debt is sustainable on the domestic market, then if 
secondary debt markets are efficient, any level of foreign debt is also sustainable in repayment equilibrium. Foreign debt can always be repaid even without exogenous default penalties, and a sufficient solution to the default problem is to improve the efficiency of secondary debt markets.

Proposition 2 shows that the assumption of lump-sum taxes is the key to deriving the Broner et al. (2010) result. Without this assumption, there is finite limit to the amount of domestic debt that can be sustained in repayment equilibrium.

Proposition 3. If taxation is costly then the government's optimal policy on the domestic market is characterized by the domestic default threshold (16). Whenever the debt is below this threshold, it is riskless and is always repaid. Whenever it is above the threshold, it will always be defaulted on and therefore can never be issued. If either output or tax distortions are stochastic, the default threshold is also stochastic, debt can be risky and default can arise in equilibrium.

Proof. The first part follows directly from comparing (11) and (13). The proof of the second part is analogous to the proof of Proposition 1.

Inequalities (15) and (16) completely characterize government policy in the second period. Notice that whenever both inequalities are reversed, it is also the case that $c^{t d}>c^{r}$, which is consistent with the definition of total default being simultaneous default on both domestic and foreign debts outstanding.

\section{Default policies in the second period}

Having established default thresholds in the second period, we posit an equilibrium in which, depending on the realizations of stochastic shocks, all four outcomes (repayment, foreign default, domestic default and total default) arise in the second period. The purpose of this part is to find a set of parameters that can sustain this equilibrium and, in the next subsection, to check that this set of parameters delivers debt issuances that are consistent with the posited equilibrium. By doing this we want to understand the mechanics and interactions between debt issuances and selective default, and prove that the set of parameters that is able to deliver the four outcomes is non-empty. Both of the stochastic processes in this economy have two outcomes. Therefore, we impose equilibrium conditions that would map the four possible realizations of joint $(y, \tau)$ stochastic processes into four equilibrium outcomes. These conditions are:

1. After a bad output shock $y_{2}=y_{L}$, the government defaults on foreign debt regardless of the realization of the tax distortion shock.

2. After a good output shock $y_{2}=y_{H}$, the government repays foreign debt regardless of the realization of the tax distortion shock. 
Figure 2: Default thresholds and selective defaults

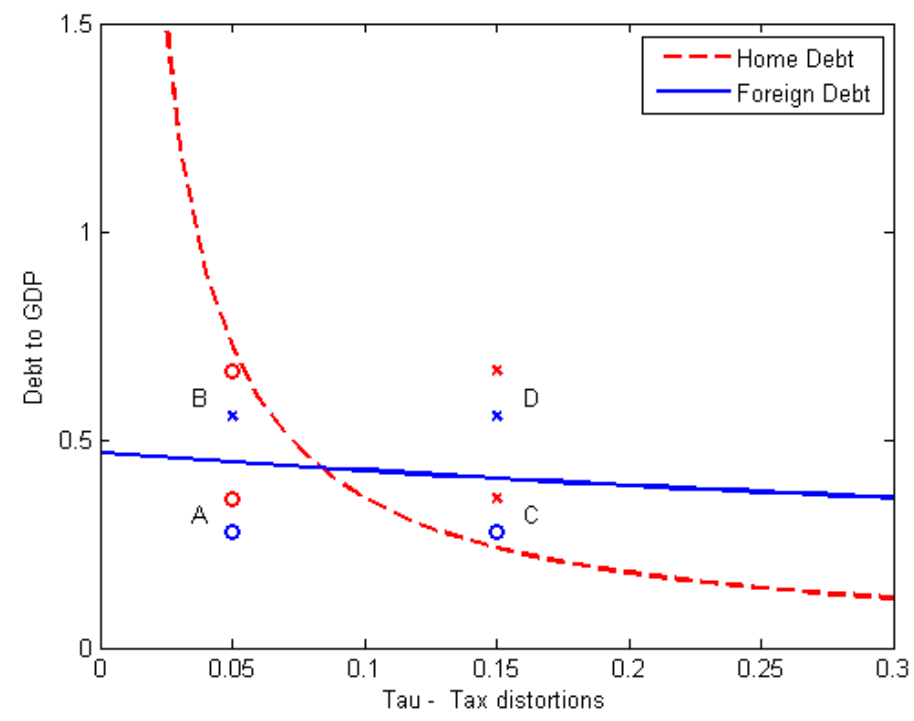

3. After a bad tax distortion shock $\tau_{2}=\tau_{H}$, the government defaults on domestic debt regardless of the realization of the output shock.

4. After a good tax distortion shock $\tau_{2}=\tau_{L}$, the government repays domestic debt regardless of the realization of the output shock.

Mathematically these conditions can be summarized by four inequalities that follow from substituting realizations of $y$ and $\tau$ into (15) and (16):

$$
\begin{aligned}
\frac{y_{L} \delta_{f}}{1+\tau_{L}} & <b_{f} \leq \frac{y_{H} \delta_{f}}{1+\tau_{H}}, \\
\frac{y_{H} \delta_{h}}{\tau_{H}} & <b_{h} \leq \frac{y_{L} \delta_{h}}{\tau_{L}},
\end{aligned}
$$

where the inequalities in (17) correspond to conditions 1) and 2) respectively, and the inequalities in (18) correspond to conditions 3) and 4) respectively. How these conditions translate into a mapping between $(y, \tau)$ outcomes and repayment-default decisions can be easily understood by looking at Figure 2. The red (dotted) line represents the domestic default threshold, while the blue (solid) line represents the foreign default threshold. In the second period, four situations may occur. Circles show allocations for which debt is repaid, while crosses show defaults. Colors represent respective debt types (red for home, blue for foreign). A negative shock to output is shown as an increase in the debt-to-GDP ratio. 
Figure 2 shows four possible outcomes denoted by letters A to D. Tax distortions $\tau$ are on the horizontal axis,

while the vertical axis represents domestic and foreign debt-to-GDP ratios in the second period $\frac{b_{h}}{y_{2}}$ and $\frac{b_{f}}{y_{2}}$. A negative output shock is shown as a move up, and a negative taxation shock is shown as a move to the right. A) After a good output shock and a good tax distortion shock, both debts fall below the default thresholds and therefore both are repaid. B) After a bad output shock and a good tax distortion shock, foreign debt (blue cross) is above its threshold and is therefore defaulted on. However, domestic debt (red circle) is still repaid, as it falls below its threshold. C) After a good output shock but bad a tax distortion shock, the situation is the reverse of B. D) After a bad output shock and a bad tax distortion shock, both debts are above default their thresholds and are therefore defaulted on.

\subsection{Debt policies in the first period}

In this section we solve for first-period debt issuance decisions that are consistent with the second-period default decisions described by (17) and (18) (or equivalently by Figure 2). In the remainder of this paper we assume a constant relative risk aversion (CRRA) instantaneous utility function for domestic agents:

$$
u(c)=\frac{c^{1-\sigma}}{1-\sigma} .
$$

The aim of this section is to first find a set of parameters for which foreign default is driven by the output shock and domestic default is driven by the tax distortion shock. The solution algorithm is provided in Solution Algorithm. We show that this set is non-empty (see Two Period Model). Second, we examine the comparative statics of an equilibrium solution.

The government chooses debt issuances $b_{h}$ and $b_{f}$ to maximize the lifetime utility of domestic agents:

$$
\max _{\left\{b_{h}, b_{f}\right\}} u\left(c_{1}\right)+\beta \mathbb{E}\left[u\left(c_{2}\right)\right]
$$

where

$$
\begin{aligned}
& c_{1}=y_{1}+\tau_{1} q_{h} b_{h}-\left(1+\tau_{1}\right)\left(g-q_{f} b_{f}\right), \\
& c_{2}=\left\{\begin{array}{l}
(11) \text { with prob. } \Pi_{y} \Pi_{\tau} \\
(12) \text { with prob. }\left(1-\Pi_{y}\right) \Pi_{\tau} \\
(13) \text { with prob. } \Pi_{y}\left(1-\Pi_{\tau}\right) \\
(14) \text { with prob. }\left(1-\Pi_{y}\right)\left(1-\Pi_{\tau}\right),
\end{array}\right.
\end{aligned}
$$

subject to price schedules derived from foreign investors' zero-profit condition and domestic households' first- 
order condition:

$$
\begin{aligned}
q_{f} & =\frac{\Pi_{y}}{1+r}, \\
q_{h} & =\beta \frac{\Pi_{y} \Pi_{\tau} u^{\prime}\left(c^{r}\right)+\left(1-\Pi_{y}\right) \Pi_{\tau} u^{\prime}\left(c^{f d}\right)}{u^{\prime}\left(c_{1}\right)} .
\end{aligned}
$$

Debt issuances must obey first-order conditions given by:

$$
\begin{aligned}
& \left(b_{h}:\right) \quad\left(\tau_{L}-\tau_{1}\right) q_{h}=\tau_{1} b_{h} \frac{\partial q_{h}}{\partial b_{h}}, \\
& \left(b_{f}:\right) \quad u^{\prime}(c)\left(\left(1+\tau_{1}\right) q_{f}+\tau_{1} b_{h} \frac{\partial q_{h}}{\partial b_{h}}\right)=\beta\left(1+\tau_{L}\right)\left(\Pi_{y} \Pi_{\tau} u^{\prime}\left(c^{r}\right)+\Pi_{y}\left(1-\Pi_{\tau}\right) u^{\prime}\left(c^{h d}\right)\right) .
\end{aligned}
$$

Comparative statics reveal that this two-period environment can account for two empirically observed facts. First, that the share of foreign investors is negatively correlated with interest rates; and second, that the share of domestic investors is positively correlated with the total public debt of the economy (see for example Andritzky (2012)). We document these findings graphically in Two Period Model. Graphical Solutions.

Now that the trade-offs behind our model have been described in detail, we can turn to quantitative analysis of an infinite-horizon version of the model.

\section{Quantitative Analysis}

We build an incomplete-markets model in which the government has limited commitment. Let time be indexed by $t=0,1,2, \ldots$ The economy has an exogenous stochastic stream of income $y_{t} \in \mathbb{Y}$, which is a Markov process. At each time $t$ the government has to cover a fixed exogenous stream of government expenditure $g_{t}$.

In each period $t$ the government decides either to repay or default on outstanding foreign and domestic debt. When the government chooses to default, the economy suffers from output penalties and is excluded from borrowing on the market where default happened for a random number of periods. We allow the expected exclusion durations and output costs to differ between types of default.

\subsection{Households}

Households are identical and risk averse. Their utility is given by:

$$
\sum_{t=0}^{\infty} \beta^{t} \mathbb{E}_{0}\left[u\left(c_{t}\right)\right],
$$

where $\beta$ is the discount factor, $c$ is consumption and $u(c)$ is increasing and strictly concave. Households are allowed to save using domestically issued government bonds $b_{h}$. They take bond discount prices and taxes as given. They 
face an intra-temporal budget constraint, which differs depending on the government's decision to default on either of the two bonds.

If the government repays both domestic and foreign debt, households' budget constraint is the following:

$$
c^{r}=y-T(1+\tau)+b_{h}-q_{h} b_{h}^{\prime},
$$

where $b_{h}$ is the amount of domestic debt owed and repaid by the government to households, $b_{h}^{\prime}$ is the new issuance of government domestic debt (household savings), $q_{h}$ is the domestic bond's discount price, $T$ is the amount of lump-sum taxes and $\tau$ is the distortion imposed by taxation. ${ }^{4}$

If the government defaults on foreign debt, households are still allowed to save in the domestic market. However, foreign default induces output costs and affects the endogenous price of domestic bonds:

$$
c^{f d}=y\left(1-\delta_{f}\right)-T(1+\tau)+b_{h}-q_{h}^{f d} b_{h}^{\prime} .
$$

In the case of domestic default, the government maintains foreign borrowing, but the domestic debt market is closed:

$$
c^{h d}=y\left(1-\delta_{h}\right)-T(1+\tau) .
$$

Similarly, in the case of simultaneous domestic and foreign default, which we will refer to as total default:

$$
c^{t d}=y\left(1-\delta_{f}\right)\left(1-\delta_{h}\right)-T(1+\tau) .
$$

\subsection{Foreign investors}

Foreigners are risk neutral investors with deep pockets and access to international credit markets, where they can save and borrow at a constant interest rate $r$. When lending resources to the government they account for the possibility of default and break even in expected terms, therefore their policy can be summarized as:

$$
q_{f}=\frac{\left(1-\Delta^{f}\right)}{1+r},
$$

where $q_{f}$ is the discount price of government bonds issued with foreign investors and $\Delta^{f}$ is the probability of foreign default.

\subsection{Recursive equilibrium}

We define a recursive equilibrium in which domestic households, foreign investors and the government act sequentially and the government acts with discretion. The aggregate state of the economy $S=\left(b_{h}, b_{f}, s\right)$ is given by two

\footnotetext{
${ }^{4}$ Whenever taxes are negative, the household budget constraint yields $c^{r}=y-T(1-\tau)+b_{h}-q_{h} b_{h}^{\prime}$, so that rebates are distortionary and distortion does not increase the amount of resources when taxes are negative. The same is true for the selective and total default cases.
} 
Figure 3: Government decision tree

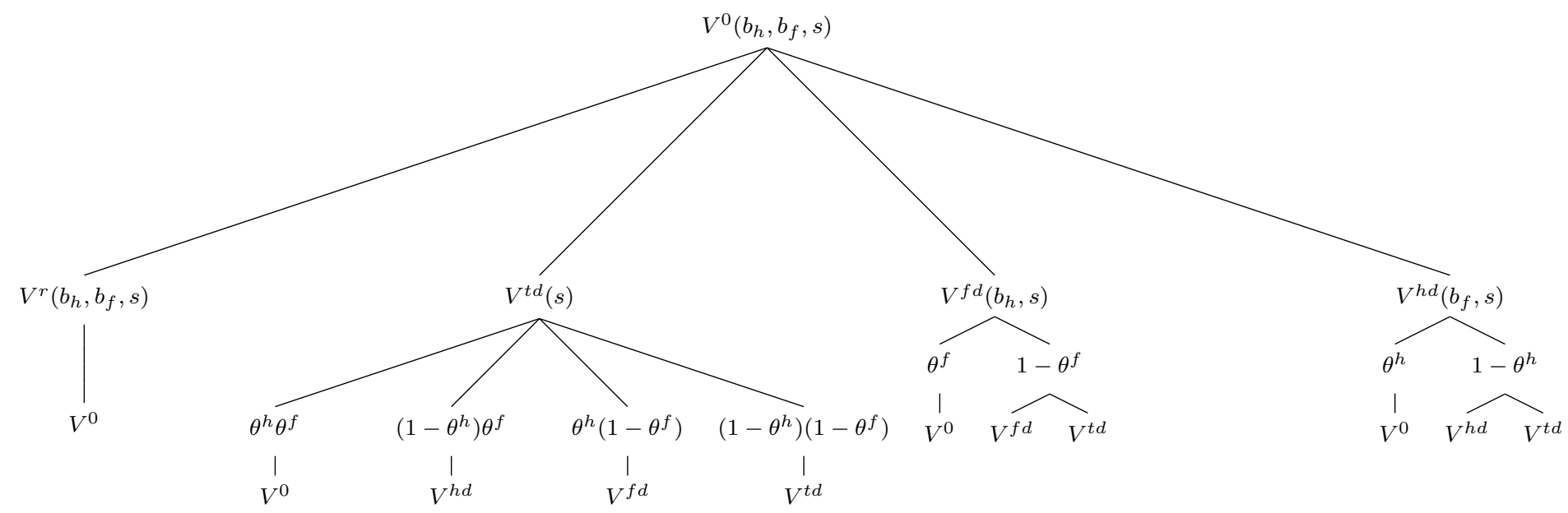

When both markets are open $\left(V^{0}\right)$, the government can decide to repay both debts $\left(V^{r}\right)$, default on both debts $\left(V^{t d}\right)$, repay only domestic debt $\left(V^{f d}\right)$ or repay only foreign debt $\left(V^{h d}\right)$. Subsequent possible choices are depicted on the lower levels of the decision tree.

endogenous debts $b_{h}, b_{f}$ and two exogenous processes for income and tax distortions $s=(y, \tau)$. Every period, the government decides whether to repay its two outstanding debts, default on domestic debt, default on foreign debt or default on both:

$$
V^{0}\left(b_{h}, b_{f}, s\right)=\max \left\{V^{r}\left(b_{h}, b_{f}, s\right), V^{f d}\left(b_{h}, s\right), V^{h d}\left(b_{f}, s\right), V^{t d}(s)\right\}
$$

The government's repayment decision is summarized by two default indicators $d_{f} \in\{0,1\}$ and $d_{h} \in\{0,1\}$, where $d_{i=\{h, f\}}=0$ stand for repayment, $d_{f}=1$ stands for foreign default and $d_{h}=1$ for domestic default. After a default, the government is excluded from borrowing on the market and faces probability $\theta_{h}, \theta_{f}$ of returning to borrowing on domestic and foreign markets respectively. The government's choices are presented graphically in Figure 3, where tree branches correspond from left to right to: repayment of both debts, default on both debts, default on foreign debt only and default on domestic debt only. After repayment, the government goes back to node $V^{0}$. After any type of default, the government first draws probabilities $\theta^{h}, \theta^{f}$ that one or the other market will open. Subsequent possible choices are depicted on the lower levels of the tree. (Total default has been put on the second branch due to graphical reasons.)

If the government decides to repay it solves the following problem:

$$
V^{r}\left(b_{h}, b_{f}, s\right)=\max _{b_{h}^{\prime}, b_{f}^{\prime}}\left\{u\left(c^{r}\right)+\beta \mathbb{E}\left\{V^{0}\left(b_{h}^{\prime}, b_{f}^{\prime}, s^{\prime}\right\}\right\}\right.
$$

subject to households' budget constraint (24), the foreign bond price schedule

$$
q_{f}\left(b_{f}^{\prime}, s\right)=\frac{\mathbb{E}\left\{1-d_{f}^{\prime}\left(b_{h}^{\prime}, b_{f}^{\prime}, s^{\prime}\right)\right\}}{1+r}
$$


and households' first-order condition:

$$
q_{h}\left(b_{h}, b_{f}, b_{h}^{\prime}, b_{f}^{\prime}, s\right)=\beta \frac{\mathbb{E}\left\{\left(1-d_{h}^{\prime}\left(b_{h}^{\prime}, b_{f}^{\prime}, s^{\prime}\right)\right) u^{\prime}\left(c^{\prime}\left(b_{h}^{\prime}, b_{f}^{\prime}, s^{\prime}\right)\right)\right\}}{u^{\prime}\left(c\left(b_{h}, b_{f}, s\right)\right)},
$$

where, unlike for foreign bonds, the price of domestic bonds depends not only on the probability of default, but also on households' welfare both today and tomorrow, and the government budget constraint

$$
T+q_{h} b_{h}^{\prime}+q_{f} b_{f}^{\prime}=g+b_{h}+b_{f} .
$$

If the government defaults on foreign debt (and keeps servicing its domestic obligations) the economy suffers an output cost, and is allowed to return to international borrowing in the future with probability $\theta^{f}$. With probability $1-\theta^{f}$ the country remains only on the domestic bond market and the government can still decide to also default on domestic bonds (yielding total default). The government's problem is summarized by:

$$
V^{f d}\left(b_{h}, s\right)=\max _{b_{h}^{\prime}}\left\{u\left(c^{f d}\right)+\beta \mathbb{E}\left(\theta^{f} V^{0}\left(0, b_{h}^{\prime}, s^{\prime}\right)+\left(1-\theta^{f}\right) \max \left\{V^{f d}\left(b_{h}^{\prime}, s^{\prime}\right), V^{t d}\left(s^{\prime}\right)\right\}\right)\right\}
$$

subject to households' budget constraint (25), households' first-order condition

$$
q_{h}^{f d}\left(b_{h}, b_{h}^{\prime}, s\right)=\beta \frac{\mathbb{E}\left\{\left(1-d^{f d^{\prime}}\left(b_{h}^{\prime}, s^{\prime}\right)\right) u^{\prime}\left(c^{f d^{\prime}}\left(b_{h}^{\prime}, s^{\prime}\right)\right)\right\}}{u^{\prime}\left(c^{f d}\left(b_{h}, s\right)\right)}
$$

(where the number of states is reduced relative to the repayment case, as foreign debt does not affect welfare because it is defaulted on) and the government budget constraint

$$
T+q_{h}^{f d} b_{h}^{\prime}=g+b_{h}
$$

Third, if the government decides to default on domestic debt outstanding, it remains active on international markets, comes back to domestic borrowing with probability $\theta^{h}$, can still default on foreign debt and suffers a domestic output penalty:

$$
V^{h d}\left(b_{f}, s\right)=\max _{b_{f}^{\prime}}\left\{u\left(c^{h d}\right)+\beta \mathbb{E}\left(\theta^{h} V^{0}\left(b_{f}^{\prime}, 0, s^{\prime}\right)+\left(1-\theta^{h}\right) \max \left\{V^{h d}\left(b_{f}^{\prime}, s^{\prime}\right), V^{t d}\left(s^{\prime}\right)\right\}\right)\right\}
$$

subject to households' budget constraint (26), the foreign bond price schedule

$$
q_{f}^{h d}\left(b_{f}^{\prime}, s\right)=\frac{\mathbb{E}\left\{1-d^{h d^{\prime}}\left(b_{f}^{\prime}, s^{\prime}\right)\right\}}{1+r}
$$

and the government budget constraint

$$
T+q_{f}^{h d} b_{f}^{\prime}=g+b_{f} .
$$


Lastly, at any given time the government can decide to pursue total default. The economy suffers output penalties for both domestic and foreign default, and the government comes back to international and domestic borrowing with probabilities $\theta^{f}$ and $\theta^{h}$ respectively. The government's problem is summarized by:

$$
V^{t d}(s)=u\left(c^{t d}\right)+\beta \mathbb{E}\left(\theta^{f} \theta^{h} V^{0}(0,0, s)+\theta^{f}\left(1-\theta^{h}\right) V^{h d}\left(0, s^{\prime}\right)+\left(1-\theta^{f}\right) \theta^{h} V^{f d}\left(0, s^{\prime}\right)+\left(1-\theta^{f}\right)\left(1-\theta^{h}\right) V^{f d}\left(s^{\prime}\right)\right)
$$

subject to households' budget constraint (27) and the government budget constraint

$$
T=g
$$

Now that actions and optimization problems are defined for each actor in the economy, we can define the equilibrium:

Definition 1. Recursive equilibrium in this economy is (i) the set of prices in repayment periods for domestic bonds $q_{h}\left(b_{h}, b_{f}, s\right)$ and foreign bonds $q_{f}\left(b_{h}, b_{f}, s\right)$ and the set of prices in partial default periods $q_{h}^{f d}\left(b_{h}, s\right)$ and $q_{f}^{h d}\left(b_{f}, s\right)$; (ii) government debt policies in repayment periods $b_{h}^{\prime}\left(b_{h}, b_{f}, s\right)$ and $b_{f}^{\prime}\left(b_{h}, b_{f}, s\right)$ and in partial default periods $b_{h}^{f d^{\prime}}\left(b_{h}, s\right)$ and $b_{f}^{h d^{\prime}}\left(b_{f}, s\right)$; and (iii) government default schedules in repayment periods $d_{h}\left(b_{h}, b_{f}, s\right)$ and $d_{f}\left(b_{h}, b_{f}, s\right)$ and in partial default periods $d_{h}^{f d}\left(b_{h}, s\right)$ and $d_{f}^{h d}\left(b_{f}, s\right)$ such that:

1) Taking as given domestic bond price schedules $d_{h}$ and $d_{h}^{f d}$ and government domestic debt issuances $b_{h}^{\prime}$ and $b_{h}^{f d^{\prime}}$, households' consumptions $c^{r}$ and $c^{f d}$ satisfy households' budget constraints and first-order conditions.

2) Taking as given government foreign default schedules $d_{f}$ and $d_{f}^{\text {hd }}$, prices $q_{f}$ and $q_{f}^{\text {hd }}$ are consistent with foreign investors' expected zero profits.

3) Taking as given prices $q_{h}, q_{f}, q_{h}^{f d}$ and $q_{f}^{h d}$, the government's default schedules $d_{h}, d_{f}, d_{h}^{f d}$ and $d_{f}^{h d}$ and debt policies $b_{h}^{\prime}, b_{f}^{\prime}, b_{h}^{f d}$ and $b_{f}^{h d}$ solve the government's optimization problem.

4) Government bond and tax policies and default schedules satisfy the government budget constraint.

\subsection{Calibration}

To solve the model numerically, we need to assume specific functional forms and assign parameters. Table 1 represents the parameters, which are selected directly from data. We assume the CRRA utility function with a risk aversion coefficient $\sigma$ equal to two. The risk-free interest rate $r$ is set to $1.7 \%$, which is the average yearly interest rate of a five-year US Treasury bond during this time period. These parameters are common values used in the real business cycle and default literatures. We calibrate the $A R(1)$ stochastic process for output, based on the series of Argentinian GDP:

$$
\log \left(y_{t}\right)=\rho_{y} \log \left(y_{t-1}\right)+u_{t},
$$

where $u_{t} \sim \mathcal{N}\left(0, \epsilon_{y}\right)$. 
Table 1: Parameters selected directly

\begin{tabular}{lll}
\hline \hline Parameter & Value & Source \\
\hline Risk-free interest rate & $r=1.7 \%$ & 5-year US bond yearly yield \\
Risk aversion & $\sigma=2$ & Standard in literature \\
Persistence of output & $\rho_{y}=0.945$ & Argentina 1993-2001 \\
Std. dev. of output & $\epsilon_{y}=0.025$ & Argentina 1993-2001 \\
Government expenditure & $g / y=0.25$ & Argentina 1993-2001 \\
Re-entry to foreign market & $\theta_{f}=0.22$ & 4.6 yrs. exclusion (R\&R 2011b) \\
Re-entry to domestic market & $\theta_{h}=0.5$ & 2 yrs. exclusion (R\&R 2011b) \\
Low tax distortion & $\tau_{l}=0.01$ & Assumed \\
\hline \hline
\end{tabular}

The government faces two types of costs upon default. The output cost is assumed to be asymmetric as in Arellano (2008):

$$
y_{t}^{d e f}=\min \left\{y_{t}, \gamma y\right\}
$$

where $y$ is the mean of the output process and $\gamma$ takes one of three values for domestic, foreign and total default respectively. The cost function implies that default is more costly with a high output realization. The level of government expenditure is set to be the average Argentinian government expenditure of $25 \%$ of GDP for the period 1993-2011. This number is not substantially different from the cross-country average of $31 \%$ for developing countries. Based on Reinhart and Rogoff (2011b) dataset we calculate the median length of domestic default to be 2.5 years and that of foreign default to be 4.6 years. ${ }^{5}$ This estimate is slightly low in comparison with the usual average exclusion period of 7.5 years for Argentina usually applied in default literature. ${ }^{6}$ Our process of tax distortions is of a reduced form and cannot be directly taken to data, therefore we make two additional assumptions. First, we assume symmetry in the process (switching states from high to low and from low to high happens with the same probability). Second, we assume taxes in the good state to be almost non-distortionary. However, $\tau_{L}$ cannot be zero (as discussed in Proposition 2) as it would make domestic debt riskless and thereby prevent the algorithm from converging.

After choosing eight parameters directly, we are left with six parameters to be calibrated. Table 2 summarizes the parameters and moments that we match. We use Reinhart and Rogoff's dataset to calculate frequencies of different types of default, periods of market exclusion and drops in output after different types of default. As in

\footnotetext{
${ }^{5}$ Calculated as the median of averages of defaulting countries

${ }^{6}$ Gelos et al. (2011) measure exclusion as the years between default and the date of the next issuance of public and publicly guaranteed bonds or syndicated loans.
} 
Table 2: Parameters selected by matching moments

\begin{tabular}{lll}
\hline \hline Parameter & Value & Target \\
\hline Discount factor & $\beta=0.95$ & Debt service to GDP 5.53\% \\
Foreign default output cost & $\gamma_{f}=0.97$ & F-default frequency $3.5 \%$ \\
Domestic default output cost & $\gamma_{h}=0.91$ & Output drop after D-default \\
High tax distortion & $\tau_{h}=0.1$ & D-debt to GDP $24.8 \%$ \\
High distortion persistence & $\pi_{h h}=0.7$ & D-default freq. 2.5\% \\
Low distortion persistence & $\pi_{l l}=0.7$ & Symmetric $\pi_{h h}=\pi_{l l}$ \\
\hline \hline
\end{tabular}

previous literature, we calibrate the discount factor to target a debt service expenditures-to-GDP ratio of $5.53 \%$. The foreign output cost $\gamma^{f}$ is calibrated to match the frequency of foreign defaults in Argentina in the last 210 years. Then, we set $\gamma^{h}$ such that the output drop after domestic default is on average three times higher than after foreign default (as documented by Reinhart and Rogoff). The persistences of distortion states are assumed to be symmetric and are set to match the frequency of domestic defaults in Argentina in the last 210 years.

Unfortunately, Reinhart and Rogoff's dataset does not report debt composition. Therefore, to calculate debt-toGDP ratios, we employ the dataset of Panizza (2008), who constructs his data based on the legal definition, which is consistent with Reinhart and Rogoff (2011b). We try to match the domestic debt-to-GDP ratio in Argentina of $24.8 \%$, although the model is not quite able to match this particular moment closely.

\subsection{Simulation results}

In this section we analyze default policies, debt policies and equilibrium prices in the calibrated model. Next we examine the quantitative performance of the model against the data. We describe the algorithm for solving the model numerically in Solution Algorithm. Both default and debt policies are four-dimensional objects, as the state space for the economy consists of two endogenous (domestic and foreign debt) and two exogenous (output and tax distortions) states. For each variable of interest, we compare policies for different levels of the same type of debt, keeping the value of the second type of debt constant.

The most interesting findings of the model are revealed by Figures 4 and 5. Figure 4 plots debt policies for foreign debt given that outstanding domestic debt is positive $b_{h}=1.8$. Foreign debt policies are similar to those found in other quantitative models of sovereign default. The country accumulates foreign debt when output is high due to low interest rates. Interest rates are low as a result of the default set being decreasing in $y$. Also, the government accumulates more debt when the economy suffers from high tax distortions. This is explained by the fact that the government avoids using distortionary taxation and instead finances its expenditures via both foreign 
Table 3: Cyclical properties

\begin{tabular}{llll}
\hline \hline & Data (Argentina) & Model & Arellano (2008) \\
\hline Foreign default frequency & $3.5 \%$ & $3.5 \%$ & $3 \%$ \\
Domestic default frequency & $2.5 \%$ & $5.6 \%$ & $\mathrm{x}$ \\
Total default frequency & $1.5 \%$ & $0.3 \%$ & $\mathrm{x}$ \\
& & & \\
Average foreign spread & $12.67 p p$ & $8.9 p p$ & $3.58 p p$ \\
Average domestic spread & $\mathrm{x}$ & $15.5 p p$ & $\mathrm{x}$ \\
& & & \\
Foreign debt-to-GDP & $17.22 \%$ & $3.7 \%$ & $5.95 \%$ \\
Domestic debt-to-GDP & $24.78 \%$ & $13.7 \%$ & $\mathrm{x}$ \\
Consumption std./ Output std. & 1.098 & 1.088 & 1.098 \\
\hline
\end{tabular}

and domestic (as we shall see) debt.

Figure 5 plots policies for domestic debt. When tax distortions are low (left panel), the government finances its expenditures in full via taxation for any level of debt outstanding. This is the situation in which raising taxes comes at the lowest cost for the economy. In fact, the government is building up assets on the domestic debt market (optimal domestic debt is the negative corner solution) in order to be able to accommodate more debt movements in the future, when distortions may be high. When tax distortions are high (right panel) and output is low, the government is in a state of default and no trade is taking place on domestic debt markets. When output is middle or high, the government employs a "gambling for redemption" policy. It finds it optimal to always increase the stock of domestic debt up to the point where it reaches endogenous debt constraints. Thus, the government is piling up domestic debt in the hope that it will be able to repay all of it with taxes, should the low-distortion day arrive. Whenever this day happens, the government repays its debt in full. If this day does not come, the government is forced to default on its domestic debt obligations.

Figures 6 and 7 plot repayment and default policies in debt-output space. White stands for repayment, light gray for foreign default, dark gray for domestic default and black for total default. We can see that the repaymentdefault trade-off for foreign debt is mostly driven by the output process, while tax distortions do not matter. On the other hand, the default area for domestic debt is much bigger for the high tax distortion than for the low tax distortion scenario. Also, as in both cases we set the second type of debt to zero, we cannot observe total default.

To assess the performance of the model, we simulate 1,000 paths from the model, each with length 10,000, and burn the first 1,000 simulations of each path. Then we compare the resulting business cycle statistics with the 
corresponding statistics from the data. Table 3 shows that the results for the benchmark calibration are in line with the data. Our model performs well in many dimensions. The model replicates reasonably high debts levels and at the same time reasonably low default probabilities. It predicts that consumption is more volatile than output, and that net exports are strongly countercyclical.

It is worth stressing once again that the two shocks have opposite effects on the economy. While the tax distortion shock has a substantial impact on domestic debt accumulation, it has a mild impact on foreign debt accumulation. The opposite is true for the output shock.

Figure 4: Foreign debt policies given $b_{h}=1.8$
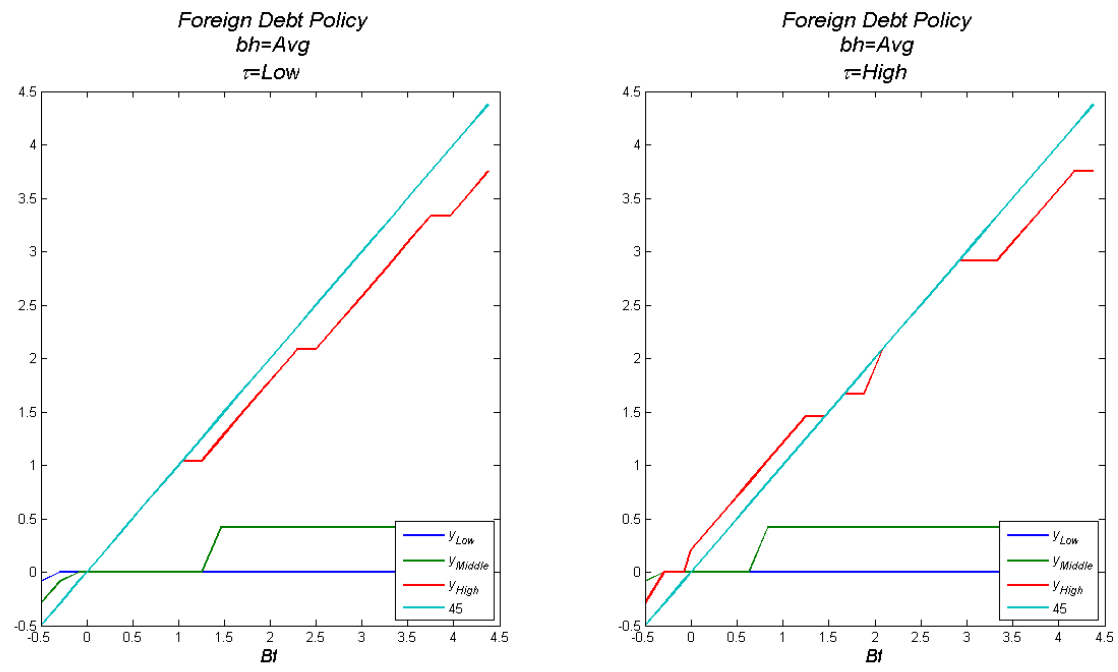

Figure 5: Domestic debt policies given $b_{f}=1.8$
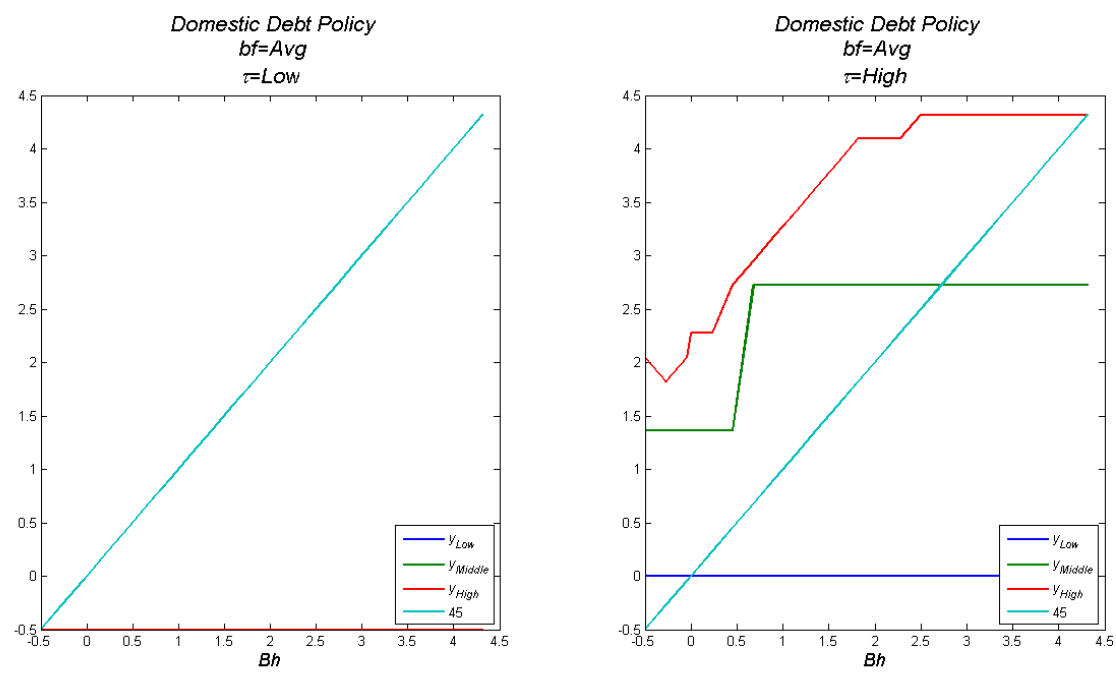
Figure 6: Default sets for foreign debt given $b_{h}=0$
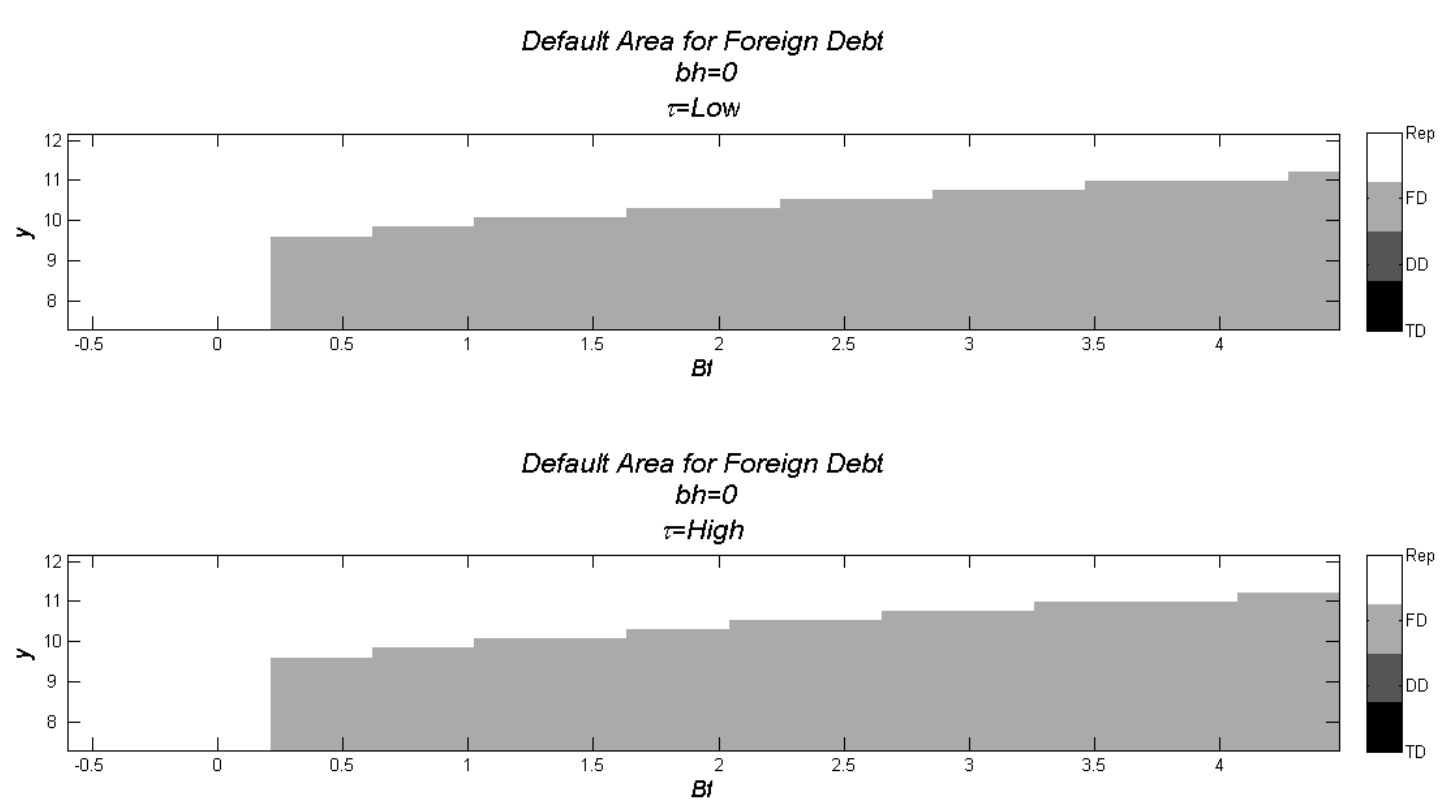

Figure 7: Default sets for domestic debt given $b_{f}=0$
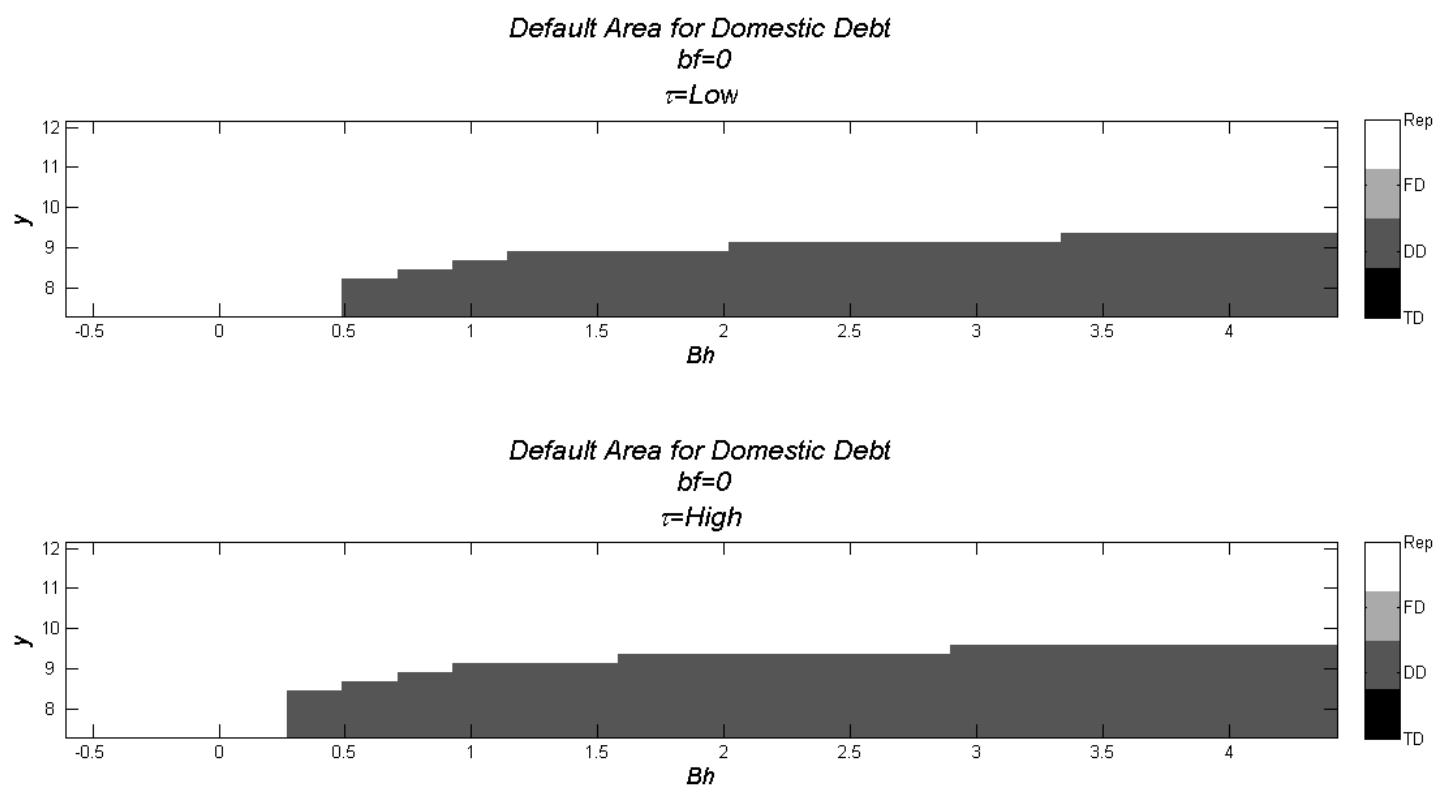


\section{$5 \quad$ Empirical Evidence}

This section confronts the two main testable implications of our model with the data. First, the model predicts foreign default is more likely in low output states of the world and is almost independent of the level of tax distortions. Second, domestic default is more likely with high tax distortions and is less dependent on the output realizations.

The idea that taxes are distortionary is not new and has been widely applied in both theoretical and empirical literature on optimal taxation and optimal level of government spending. In this paper we abstract from these considerations, but take an insight by Browning (1976) as a starting point. The social cost of financing a marginal dollar of public expenditure is the sum of that dollar, which is diverted from private use plus the change in the total welfare cost of taxation caused by increasing tax revenue by the dollar. Stuart (1984) terms the latter component

"marginal excess burden" and its definition fits our notion of tax distortions $\tau$ perfectly. The are numerous studies that estimate "marginal excess burden" using quantified theory. Harberger (1964) classic estimate puts it at around 2.5 per additional dollar raised, while Browning (1976) using the same formula calculates it to be between 9 16 cin 1974. Stuart (1984) proposes a new, general equilibrium approach, which results in estimates being 1.5 times those of Browning. Seminal contribution by Feldstein (1999) using micro level data and accounting for multiple channels of adjustments to tax code changes puts an average dead-weight loss from personal income tax at $32,2 \%$ and, more importantly, shows that marginal losses can be as high as $2 \$$ per additional $1 \$$ raised. Our takeaway from this literature is that tax distortions $\tau$ are significant, positive and variable ${ }^{7}$.

To test our two main predictions we collect the data on both types of defaults, domestic and foreign, and the data on output and taxes. However, there is no readily available measure of tax distortions. The next section explains how we construct a proxy for this.

\subsection{Methodology}

The tax revenue from a specific tax $T R_{i}$ is by definition equal to the product of the tax rate $t r_{i}$ and the tax base $T B_{i}$.

$$
T R_{i}=t r_{i} \times T B_{i}
$$

If a tax is non-distortionary, a change in the tax rate does not affect the tax base. If a tax is distortionary, a change of the tax rate would reduce the tax base. A visual example of this effect is the Laffer curve. When a tax rate increases in the range close to 0 revenue also goes up almost one-to-one. The higher is the tax rate however, increases in revenue are slowing down, as tax base is decreasing (tax distortions start playing a role). At some point

\footnotetext{
${ }^{7}$ When marginal burden is different from average burden as in Feldstein (1999) then any exogenous change in a tax code would result in a change in an average burden.
} 
maximum is reached, above which reduction in tax base dominates any increase in tax rate and tax revenue goes down.

Moreover, if a government undertakes any changes (decreasing deductions, taming tax avoidance, making labor more inelastic etc.) so that a tax base goes up without any change it a tax rate, if more income could be raised with the same primary tool, this should be also seen as a reduction in tax distortions.

Hence, we any change in the tax base $T R_{i}$ is a sufficient proxy for the change in tax distortions (model $\tau_{i}$ ).

\subsection{Data}

The data on default, as described in the second section of this paper, comes from the updated database accompanying Reinhart and Rogoff (2011b) and covers up to 130 countries for the years 1800-2014. From this database we obtain our dependend variables, dummy indicators for foreign $D e f^{f}$ and domestic $D e f^{d}$ default.

Output data we obtain from Penn World Tables 8.1 (Feenstra et al. (2015)) which cover up to 209 countries for the years 1950-2011. Data on tax revenues comes from The ICTD Government Revenue Dataset (Prichard et al. (2014)) which covers up to 130 countries for the years 1980-2010. Finally, data on tax rates we have obtained and compiled from two main sources: World Tax Database (WTD) by Office of Tax Policy Research (2015) (up to 60 countries between 1950 and 2002) which is our primary source on corporate income tax rates and World Tax Indicators (WTI) by Andrew Young School of Policy Studies (2010) (up to 180 countries for the years 1981-2005) which is our primary source on individual income tax rates. These are complemented by two further sources: Oxford University Centre for Business Taxation (2015) (CBT; up to 48 countries for the years 1979-2014) and KPMG (2015) (up tp 79 countries for the years 2002-2014). All our variables come in yearly frequency. Our estimation sample with the full data coverage is 89 countries for the years 1981-2011 yielding a total of 1432 country-year observations.

\subsection{Estimation}

We estimate the following two regression equations:

$$
\begin{aligned}
& \operatorname{Pr}\left(D e f_{i, t}^{f}=1\right)=\alpha_{0}^{f}+\alpha_{1}^{f} G D P_{i, t-1}+\alpha_{2}^{f} T B_{i, t-1} \\
& \operatorname{Pr}\left(D e f_{i, t}^{d}=1\right)=\alpha_{0}^{d}+\alpha_{1}^{d} G D P_{i, t-1}+\alpha_{2}^{d} T B_{i, t-1}
\end{aligned}
$$

where Def is a default indicator and $\operatorname{Pr}$ probability of default in country $i$ in period $t$. Deff is an indicator for the beginning of a foreign default episode. It takes value 1 if a country $i$ was in a foreign default in year $t$, but was not in a foreign default in year $t-1$ and 0 otherwise. Def $f^{d}$ is an indicator for the beginning of a de facto domestic default episode, which includes both de jure domestic default and a hyperinflation crisis. It takes value 1 
Table 4: Foreign Default

\begin{tabular}{lcccc}
\hline \hline & $(1)$ & $(2)$ & $(3)$ & $(4)$ \\
& Probit RE & Logit RE & Logit FE & Logit Pooled \\
\hline GDP & $-0.509^{* *}$ & $-0.940^{* *}$ & -0.505 & $-0.904^{* *}$ \\
& $(0.180)$ & $(0.328)$ & $(0.340)$ & $(0.300)$ \\
\multirow{2}{*}{ Tax Base } & -0.0302 & -0.0808 & -0.187 & -0.0780 \\
& $(0.0208)$ & $(0.0538)$ & $(0.102)$ & $(0.0512)$ \\
\hline r2 & & & & \\
$\mathrm{N}$ & 1490 & 1490 & 371 & 1490 \\
\hline \hline
\end{tabular}

Standard errors in parentheses

${ }^{*} p<0.05,{ }^{* *} p<0.01,{ }^{* * *} p<0.001$

if a country $i$ was either in a domestic default or in a hyperinflation crisis in year $t$, but was in neither in year $t-1$ and 0 otherwise ${ }^{8}$.

$G D P$ is the rate of growth of real GDP per capita denominated in fixed US dollars and $T B$ is the Tax Base calculated from equation (43). Our independent variables are lagged one period to avoid possible endogeneity problem. In regressions we use Tax Base for both corporate taxes. There is a good rationale for that. Corporate taxes are, to the best of our knowledge, always flat-rate taxes. This is however not true for personal income taxes, which are usually progressive. Our data sources have good coverage of the highest rate of the personal income tax, which is far from being a good proxy for the average effective rate of the personal income tax. Our model implies that foreign default is mostly driven by fluctuations in output and is almost independent from tax distortion shock, therefore we expect $\alpha_{1}^{f}$ to be significant and negative and $\alpha_{2}^{f}$ to be zero. On the other hand, in our model domestic default is driven mostly by tax distortion shock but also depends on output shock. Fluctuations in tax distortions $\tau$ are inversely related to fluctuations in a tax base $T B$ as explained in the Methodology subsection. Therefore we expect $\alpha_{2}^{d}$ to be significant and positive and $\alpha_{2}^{f}$ to be non-positive.

We run two benchmark and two robustness regressions for each foreign and domestic default. As a benchmark we run probit and logit with random effects. To check robustness of our results we complement those two pooled logit and logit with fixed effects.

Table 4 presents regression results for the foreign default, that is equation (44). The estimate of the coefficient of the rate of growth of real GDP is positive and significant, while changes in the tax base do not affect the probability of the foreign default. This result confirms our hypothesis, that foreign default is driven by the output fluctuations

\footnotetext{
${ }^{8}$ Following Reinhart and Rogoff (2011b) these crises are defined as follows: foreign default is defined as the failure to meet principal or interest payment on a due date. This definition also applies for domestic default. The distinction between domestic and foreign default is based on legal definition of debt. In addition, domestic debt crises have involved the freezing of bank deposits and or forcible conversions. An inflation crisis occurs when annual inflation is 20 per cent or higher.
} 
Table 5: Domestic Default

\begin{tabular}{lcccc}
\hline \hline & $(1)$ & $(2)$ & $(3)$ & $(4)$ \\
& Probit RE & Logit RE & Logit FE & Logit Pooled \\
\hline GDP & -0.0294 & -0.00184 & 0.387 & -0.177 \\
& $(0.279)$ & $(0.584)$ & $(0.774)$ & $(0.424)$ \\
\multirow{2}{*}{ Tax Base } & $-0.0479^{*}$ & $-0.110^{*}$ & $-0.127^{*}$ & $-0.0958^{*}$ \\
& $(0.0225)$ & $(0.0512)$ & $(0.0639)$ & $(0.0407)$ \\
\hline r2 & & & & \\
$\mathrm{N}$ & 1496 & 1496 & 387 & 1496 \\
\hline \hline
\end{tabular}

Standard errors in parentheses

${ }^{*} p<0.05,{ }^{* *} p<0.01,{ }^{* * *} p<0.001$

and tax distortions do not play any significant role.

Table 5 presents results for the domestic default, that is equation (45). As can be seen, the higher is the tax base (which corresponds to the lower distortions) the lower is the probability of domestic default. As expected, the impact of the corporate tax base is negative and significant. The real rate of GDP growth however, has no impact on domestic default. This confirms our second hypothesis, that domestic default is more likely with high tax distortions and is less dependent on the output realizations.

\section{Secondary Markets and Haircuts}

With the introduction of unconventional monetary policies during the Great Recession, secondary sovereign debt markets have attracted increasing interest among economists. In this section we return to the two-period model setting from Section 3 to study how secondary markets affect the government's incentives to repay or to default. We will introduce secondary markets in the second period. Secondary markets open after nature selects the output and taxation shocks. Therefore all participants in the market have perfect foresight of what the government will do (repay or default) if no trade in assets takes place on secondary markets.

\subsection{Setup}

The starting points for the discussion are Propositions 1, 2 and 3, where we have established that with costly tax enforcement there exist finite default thresholds for both foreign and domestic debt, and that both debts can be risky due to the stochastic nature of output and taxation distortions. There are four possible outcomes of the model in the moment at which secondary markets open, which are summarized in Figure 2. When either both debts are repaid (situation A) or defaulted on (situation D), the workings of the secondary markets would not change the 
final outcome. Therefore our discussion will focus on selective foreign default (situation B). ${ }^{9}$ Under situation B in the second period output is low $y_{2}=y_{L}$ and tax distortions are low $\tau_{2}=\tau_{L}$.

First we will summarize our assumptions about what is happening in the economy at the moment the secondary markets open, and we introduce some notation. As long as default costs are positive, there are positive amounts of both foreign and domestic debts outstanding: $b_{f}$ and $b_{h}$. Each debt has its respective default threshold which we derive from (15) and (16) and denote in levels: $\bar{B}_{f}$ and $\overline{B_{h}}$.

After a good shock to taxation and a bad shock to output, foreign debt is above its default threshold $b_{f}>\bar{B}_{f}$ but domestic debt lies below its default threshold $b_{h}<\overline{B_{h}}$. As foreigners know they will be defaulted upon, they are willing to sell their claims in the secondary market. As domestic investors know there is still some room for an increase in repayable domestic debt, they are willing to buy them. Bonds in the secondary market sell at discount price $q^{S M}$.

For the sake of consistency with the model we keep track of domestic debt outstanding. However, our analysis is also valid for the case when $b_{h}=0$, as in Broner et al. (2010). Therefore we can see this section as a generalization of their work in which we allow for costly enforcement. ${ }^{10}$ As we shall see, what matters for creating repayment incentives through secondary markets is not the level of home or foreign debt outstanding, but the relative difference between above-the-threshold foreign holdings $b_{f}-\bar{B}_{f}$ and below-the-threshold domestic accommodation space $\overline{B_{h}}-b_{h}$. We will call the former expression "defaultable foreign debt overhang" and the latter "domestic debt accommodation space".

We formulate this situation as a noncooperative game. There are three types of agents: domestic investors, foreign investors and the government. First, both populations of investors take simultaneous decisions on the amounts supplied and demanded in the secondary market given the secondary market discount price and beliefs about the government's subsequent action (default or repay). After trades have taken place, the secondary market closes and the government decides to either repay or default on foreign and domestic investors.

Foreign investors' strategy space is the quantity of bonds supplied in the secondary market:

$$
s^{f}=\left\{b_{f}^{S M}\left(q^{S M}, d_{f}^{S M}\right)\right\}, \quad x_{f} \in\left[0, b_{f}\right] .
$$

Domestic investors' strategy space is quantity demanded in the secondary market:

$$
s^{h}=\left\{b_{h}^{S M}\left(q^{S M}, d_{h}^{S M}\right)\right\}
$$

The government's strategy space consists of two decisions (repay or default) on the two markets:

$$
s^{g}=\left\{d_{f}^{S M} \times d_{h}^{S M}\right\}, \quad d_{f}^{S M} \in\{0,1\}, \quad d_{h}^{S M} \in\{0,1\} .
$$

\footnotetext{
${ }^{9}$ Selective domestic default, situation $\mathrm{C}$, is its mirror image.

${ }^{10}$ In Broner et al. (2010), a government with discretion wants to default on foreign debt because it faces no penalties upon default $\delta^{f}=0$. In our analysis, foreign default is due to the government's discretionary behavior with $\delta^{f}>0$ and an unfortunate output shock.
} 
Given strategies of the three players we can define payoffs for each player. Because of risk neutrality of the foreign investor her payoff is defined as her consumption in the second period and is the function of her decision (quantity supplied on the secondary market $b_{f}^{S M}$ ), domestic investor's decision (quantity demanden on the secondary market $b_{h}^{S M}$ ) and the government's decision (to default or repay foreign debt $d_{f}^{S M}$ ):

$$
U^{f}\left(b_{h}^{S M}, b_{f}^{S M}, d_{f}^{S M}\right)= \begin{cases}\left(b_{f}-b_{f}^{S M}\right)+q^{S M} b_{f}^{S M} & \text { if } d_{f}^{S M}=0 \text { and } b_{f}^{S M}=b_{h}^{S M} \\ q^{S M} b_{f}^{S M} & \text { if } d_{f}^{S M}=1 \text { and } b_{f}^{S M}=b_{h}^{S M} \\ b_{f} & \text { if } d_{f}^{S M}=0 \text { and } b_{f}^{S M} \neq b_{h}^{S M} \\ 0 & \text { if } d_{f}^{S M}=1 \text { and } b_{f}^{S M} \neq b_{h}^{S M}\end{cases}
$$

where $b_{f}$ is the amount of government bonds that foreign investors hold from the first period and $q^{S M}$ is the discount price of bonds on the secondary market in the second period. The first two cases of equation (46) refer to a situation when demands meets supply and there is trade in bonds on the secondary market. The last two cases refer to a situation when there is no trade on the secondary market. On the other hand first and third case of equation (46) describe payoffs to a foreign investor when the government repays foreign debt, whereas second and fourth case describe payoffs to a foreign investor when the governments defaults on foreign debt.

Similarly, we define the payoff for the domestic investor. Her payoff differs from foreign investor's payoff mainly due to risk aversion. The payoff of the domestic investor is the utility from consumption $(u(c)$ as defined in equation (19)) in the second period after secondary market closes. The domestic investor decides on the quatity demanded in the secondary market $b_{h}^{S M}$ taking the supply of bonds from foreign investors $b_{f}^{S M}$ and the government decision to default or repay domestic debt $d_{h}^{S M}$ as given:

$$
U^{h}\left(b_{h}^{S M}, b_{f}^{S M}, d_{f}^{S M}\right)= \begin{cases}u\left(y_{2}+b_{h}+b_{h}^{S M}\left(1-q^{S M}\right)-T_{2}\left(1+\tau_{2}\right)\right) & \text { if } d_{h}^{S M}=0 \text { and } b_{f}^{S M}=b_{h}^{S M} \\ u\left(y_{2}-q^{S M} b_{h}^{S M}-T_{2}\left(1+\tau_{2}\right)\right) & \text { if } d_{h}^{S M}=1 \text { and } b_{f}^{S M}=b_{h}^{S M} \\ u\left(y_{2}+b_{h}-T_{2}\left(1+\tau_{2}\right)\right) & \text { if } d_{h}^{S M}=0 \text { and } b_{f}^{S M} \neq b_{h}^{S M} \\ u\left(y_{2}-T_{2}\left(1+\tau_{2}\right)\right) & \text { if } d_{h}^{S M}=1 \text { and } b_{f}^{S M} \neq b_{h}^{S M}\end{cases}
$$

Finally, the government moves after the secondary market closes. The government decides whether to default of repay both debts $d_{h}^{S M}, d_{f}^{S M}$ taking $b_{h}^{S M}$ and $b_{f}^{S M}$ as given and its payoff is defined by (47). The government decision boils down to two default thresholds policies as shown in derivations (11)-(16). These policies, given the 
trade on the secondary market in the second period, translate to:

$$
\begin{gathered}
d_{h}^{S M}\left(b_{h}^{S M}, b_{f}^{S M}\right)= \begin{cases}0 & \text { if } b_{h}+b_{h}^{S M} \leq \overline{B_{h}} \\
1 & \text { if } b_{h}+b_{h}^{S M}>\overline{B_{h}}\end{cases} \\
d_{f}^{S M}\left(b_{h}^{S M}, b_{f}^{S M}\right)= \begin{cases}0 & \text { if } b_{f}-b_{f}^{S M} \leq \overline{B_{f}} \\
1 & \text { if } b_{f}-b_{f}^{S M}>\overline{B_{f}}\end{cases}
\end{gathered}
$$

A Nash equilibrium of this game is the triplet of strategies $\left\{s_{f *}, s_{h *}, s_{g_{*}}\right\}$ for which quantity demanded $b_{h}^{S M}$ equals quantity supplied $b_{f}^{S M}$ given market clearing price $q^{S M *}$ and beliefs of investors are consistent with the government decisions $d_{h}^{S M *}, d_{f}^{S M *}$ :

$$
\begin{aligned}
& b^{S M *}=b_{f}^{S M}\left(q^{S M *}, d_{f}^{S M *}\right)=b_{h}^{S M}\left(q^{S M *}, d_{h}^{S M *}\right) \\
& d_{h}^{S M *}=d_{h}^{S M}\left(b_{h}^{S M *}, b_{f}^{S M *}\right) \\
& d_{f}^{S M *}=d_{f}^{S M}\left(b_{h}^{S M *}, b_{f}^{S M *}\right)
\end{aligned}
$$

We split our analysis into two parts. In the first, we analyze the situation when foreign debt overhang is greater than domestic debt accommodation space $\left(b_{f}-\bar{B}_{f}\right)>\left(\bar{B}_{h}-b_{h}\right)$. That is, in order to be repaid, foreign investors have to sell more bonds than domestic investors can accommodate and still be repaid. It is thus impossible that both groups be repaid after the secondary market closes. In the second part, we analyze the reverse situation, when foreign debt overhang is smaller than domestic debt accommodation space $\left(b_{f}-\bar{B}_{f}\right)<\left(\bar{B}_{h}-b_{h}\right)$. In this situation domestic investors can safely buy what foreign investors need to supply in order to be repaid. In theory, secondary markets could allow both groups of investors to be repaid.

We will look for Nash equilibria in pure strategies with continuous strategy sets. The precise outcomes of the model will depend on the assumptions we make about the possibility of investor coordination and of voluntary debt haircuts. In terms of investor coordination, we consider two different cases. First, we consider the case in which the set of investors is a continuum (infinite number of investors, each investor has size zero). Second, we modify this assumption and introduce a finite number of investors (each investor has size $\epsilon$ ). This theoretical notion has a very intuitive interpretation in our game. By assumption, a zero-size investor does not internalize the effects of her individual decision on aggregate action of the set of investors of her class (domestic or foreign), whereas an $\epsilon$-size investors does. If there are externalities in this game (and we shall see that indeed externalities arise) then an $\epsilon$-size investor internalizes them. Therefore it is equivalent to say that zero-size investors cannot coordinate their actions while $\epsilon$-size investors can coordinate. For each of the two parts (foreign debt overhang dominates, domestic accommodation space dominates) we will analyze four cases, when each set of investors either can or cannot coordinate. 
Table 6: Secondary Markets and Haircuts

when Foreign Debt Overhang is Greater

\begin{tabular}{|c|c|c|c|}
\hline & \multicolumn{2}{|c|}{ Foreign Investors } \\
\hline & & Coordinate & Don't coordinate \\
\hline \multirow{2}{*}{ Domestic Investors } & Coordinate & $\begin{array}{l}\mathrm{FD}\left(\delta^{f}\right) ; b^{S M} \in\left(\overline{B_{h}}-b_{h}, b_{f}-\overline{B_{f}}\right) \\
\text { SM reduce welfare } \\
\text { Haircut equilibrium restores repayment }\end{array}$ & $\begin{array}{l}\mathrm{FD}\left(\delta^{f}\right) ; b^{S M}=\overline{B_{h}}-b_{h} \\
\text { SM reduce welfare } \\
\text { No Haircut equilibrium }\end{array}$ \\
\hline & Don't coordinate & $\begin{array}{l}\mathrm{DD}\left(\delta^{h}\right) ; b^{S M}=b_{f}-\overline{B_{f}} \\
\text { SM likely increase } \\
\text { Haircut equilibrium restores repayment }\end{array}$ & $\begin{array}{l}\mathrm{TD}\left(\delta^{f}+\delta^{h}\right) \\
\text { SM reduce welfare } \\
\text { No Haircut equilibrium }\end{array}$ \\
\hline
\end{tabular}

The second important assumption is either forbidding or allowing free disposal. When free disposal is forbidden, the amount of bonds issued must be equal to the amount of bonds claimed. When free disposal is allowed, each investor can voluntarily burn some of her bonds, so the amount of bonds claimed can be lower than the amount of bonds issued. Free disposal also has a very intuitive interpretation in our example. When free disposal is allowed and exercised, we can think of this as a voluntary debt haircut.

Table 6 gives a brief summary of the results of secondary markets and haircuts, when foreign debt overhang dominates. We are initially, before the secondary market opens, in situation B: the economy would suffer the foreign default $\operatorname{cost} \delta^{f}$ and the amount of domestic debt $b^{h}$ needs to be either rolled over or repaid by distortionary taxation. If trade on the secondary market does not alter the outcome in terms of default of the primary market (the first row of Table 6), any trade on secondary market is undesirable from the welfare point of view, because it either increases the risk of default or induces dead-weight losses of distortionary taxation. If trade on the secondary market alters the outcome in terms of default of the primary market(the second row of Table 6), the welfare analysis is ambiguous in some cases. However, we can provide intuition for some cases. First, if both domestic and foreign investors are infinitesimal, the economy suffers the output loss $\left(1-\delta^{f}\right)\left(1-\delta^{h}\right) y$ upon total default instead of the output loss $\left(1-\delta^{f}\right) y$ upon foreign default, but both debts are set to zero. However, if it was desirable to have total default from the welfare point of view, total default would happen on primary market. Second, if foreign investors are $\epsilon$-size and domestic investors are infinitesimal, the economy suffers the output loss $\left(1-\delta^{h}\right) y$ upon domestic default instead of the output loss $\left(1-\delta^{f}\right) y$ upon foreign default and a substantial reduction of foreign debt.

Table 7 gives a brief summary of the results of secondary markets and haircuts, when domestic accommodation space dominates. We are initially, before the secondary market opens, in situation B: the economy would suffer the foreign default $\operatorname{cost} \delta^{f}$ and the amount of domestic debt $b^{h}$ needs to be either rolled over or repaid by distortionary taxation. Trade on the secondary market restores repayment of both debt. if both domestic and foreign investors are infinitesimal, the economy suffers the output loss $\left(1-\right.$ delta $\left.^{f}\right)\left(1-\right.$ delta $\left.^{h}\right) y$ upon total default instead of the 
Table 7: Secondary Markets and Haircuts

when Domestic Accommodation Space is Greater

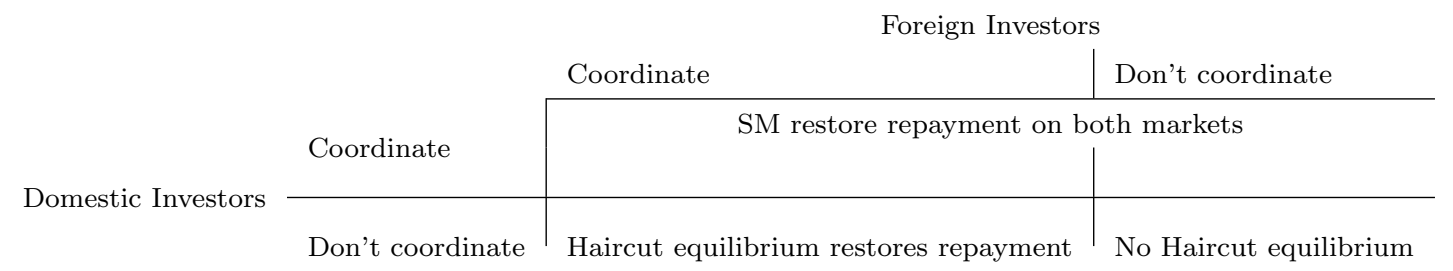

output loss $\left(1-\operatorname{delta}^{f}\right) y$ upon foreign default, but both debts are set to zero. However, if it was desirable to have total default from the welfare point of view, total default would happen on primary market. Second, if foreign investors are $\epsilon$-size and domestic investors are infinitesimal, the economy suffers the output loss $\left(1-\right.$ delta $\left.^{h}\right) y$ upon domestic default instead of the output loss $\left(1-\operatorname{delta}^{f}\right) y$ upon foreign default and a substantial reduction of foreign debt.

\subsection{Equilibria when foreign debt overhang dominates}

Proposition 4. If both domestic and foreign investors are infinitesimal (cannot coordinate) and the defaultable foreign debt overhang is greater than the domestic debt accommodation space:

a. Nash equilibrium is indeterminate and degenerate.

b. $b^{S M} \in\left(\bar{B}_{h}-b_{h}, b_{f}-\bar{B}_{f}\right), \quad q^{S M}=0$.

c. Both debts are defaulted on: $d_{h}^{S M}=1, \quad d_{f}^{S M}=1$.

Proof. See Appendix 8.4.

The only Nash equilibrium under this specification of the game is indeterminate and occurs at a discount price equal to zero. This specification of the game suffers from a well known equilibrium existence problem due to discontinuous payoffs (see Dasgupta and Maskin (1986a) and Dasgupta and Maskin (1986b)). Because of discontinuous payoffs, the best response functions of both investors do not cross at any positive price, which is demonstrated in the proof of the proposition.

Proposition 4 shows then that under certain circumstances secondary markets do not help create incentives for repayment of government debt, when those incentives are absent on the primary market. Moreover, as the equilibrium is indeterminate and degenerate, the outcome of secondary market trade is uncertain. This result may shed some light on why, in turbulent times, secondary markets may cease to function. Russia in 1998 effectively defaulted on its obligations towards households but repaid its obligations to firms. Why there was no significant 
re-trade of bonds between households and firms on the secondary market remains an open question, but this proposition may provide some intuition.

We investigate this result further in altering the assumptions that neither domestic nor foreign investors can coordinate their actions. We formalize this idea by relaxing the assumption of each investor being zero-measure. Instead we assume that the measure of each investor is $\epsilon>0$, so that the economy is populated by $\frac{1}{\epsilon}$ investors.

Proposition 5. If domestic investors are $\epsilon$-size (are able to coordinate) and the defaultable foreign debt overhang is greater than the domestic debt accommodation space:

a. Nash equilibrium in pure strategies is indeterminate but yields a unique allocation.

b. $b^{S M}=\bar{B}_{h}-b_{h}, \quad q^{S M}=0$.

c. Domestic debt is repaid $d_{h}^{S M}=0$ and foreign debt is defaulted on $d_{f}^{S M}=1$.

Proof. See Appendix 8.4.

Figure 8: Trade in secondary markets improves welfare (Proposition 5)

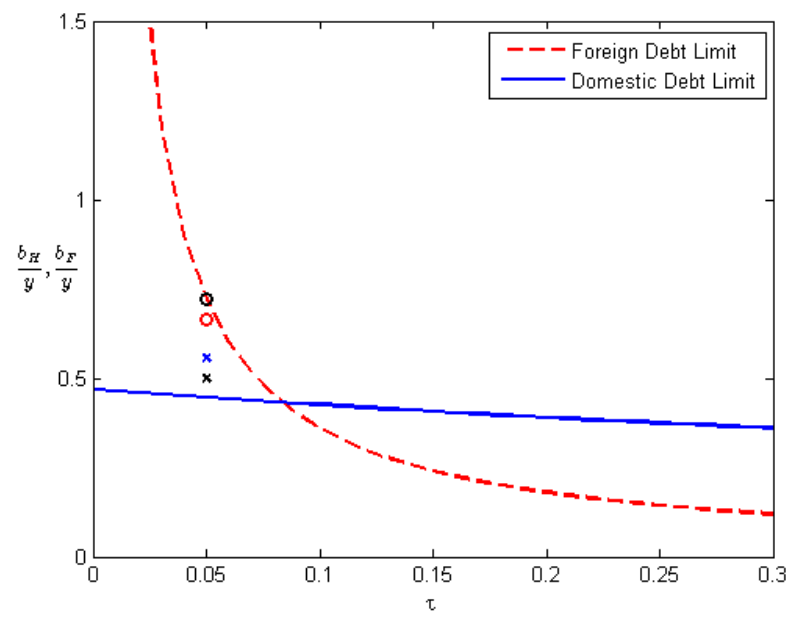

The result in Proposition 5 is graphically depicted in Figure 8. The red circle and the blue cross show the situation before trade on the secondary market. With trade, domestic investors increase their holdings up to their default threshold and are repaid (black circle). Foreign investors decrease their holdings, but are nevertheless defaulted on (black cross) as their bond holdings are still above the default threshold. Note that the equilibrium in Proposition 5 holds when foreign investors both can and cannot coordinate. The ability to coordinate among domestic investors is not only a sufficient condition to sustain repayment incentives on the domestic market, but also allow domestic investors to capture the whole surplus generated by trade on the secondary market $\left(q^{S M}=0\right)$. 
Hence, trade on the secondary market does not affect welfare of foreign investors.

Lastly, let us study the reverse situation. Now foreign investors can coordinate and domestic investors are all zero-measure.

Proposition 6. If foreign investors are $\epsilon$-size (are able to coordinate), domestic investors are infinitesimal (cannot coordinate) and the defaultable foreign debt overhang is greater than the domestic debt accommodation space:

a. Nash equilibrium in pure strategies is unique and degenerate.

b. $b^{S M}=b_{f}-\bar{B}_{f}, \quad q^{S M}=0$.

c. Domestic debt is defaulted on $d_{h}^{S M}=1$ and foreign debt is repaid $d_{f}^{S M}=0$.

Proof. See Appendix 8.4.

Figure 9: Trade in secondary markets destroys welfare (Proposition 6)

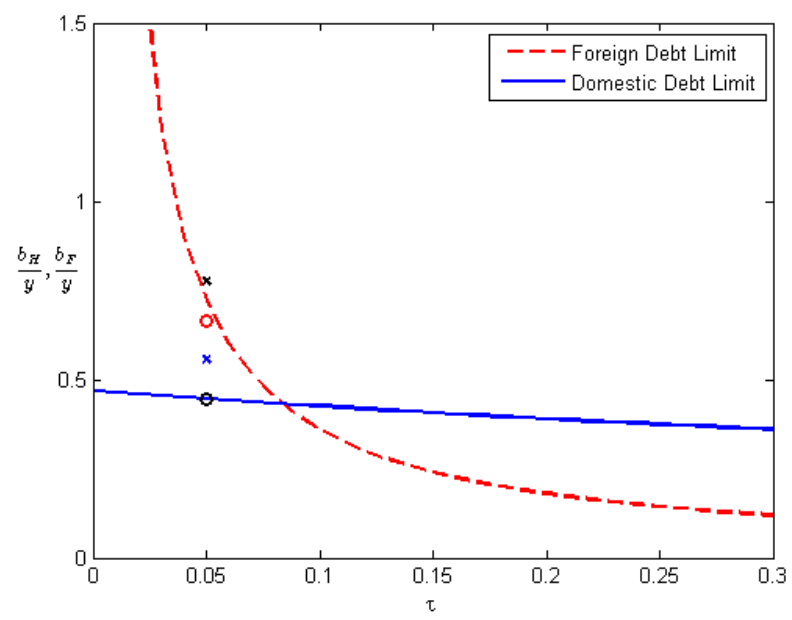

Proposition 6 shows an interesting result. Under the mix of unfavorable circumstances for domestic investors (a low accommodation space relative to the foreign debt overhang, and a lack of domestic coordination while foreign investors can coordinate), introducing a secondary market reverses the selective default result that would otherwise occur on the primary market.

This situation is shown in Figure 9. Again, the blue cross and the red circle stand for the situation before secondary markets open (foreign default and domestic repayment). Now foreign investors are able to re-trade their defaultable debt overhang to home investors, and are repaid by the government (black circle). Domestic investors exceed the domestic debt default threshold and are defaulted on by the government (black cross). Instead of defaulting on its foreign obligations, the government defaults on domestic debt holdings, and foreign obligations are 
repaid.

Proposition 7. If foreign investors are allowed free disposal and are $\epsilon$-size (can coordinate):

a. The game is reduced to two players: foreign investors and the government.

b. Equilibrium is unique.

c. $b_{f}-\bar{B}_{f}$ is freely disposed of.

d. Both debts are repaid: $d_{h}=0$ and $d_{f}=0$.

Proof. See Appendix 8.4.

Proposition 8. If foreign investors are allowed free disposal and are infinitesimal (cannot coordinate), the Nash equilibrium in pure strategies does not exist.

Proof. See Appendix 8.4.

Propositions 7 and 8 show that voluntary haircuts would occur only when foreign investors are able to coordinate. This is because without coordination each investor has incentives to deviate from the haircut allocation and freely dispose less than $b_{f}-\bar{B}_{f}$, not expecting this would change the government's decision. After a voluntary haircut, foreign debt is repaid. Domestic debt is unaffected and also repaid. Interestingly, voluntary haircuts increase welfare and restore repayment incentives in situations when secondary markets may fail to deliver a well-behaved equilibrium (Proposition 6).

Results in this section may shed some light on the Greek government debt crisis, when in 2012 private investors agreed to a voluntary haircut while the trade of government bonds on secondary markets was negligible.

\subsection{Equilibria when domestic accommodation space dominates}

In this part we analyze the situation in which the foreign debt overhang is smaller than the domestic debt accommodation space $\left(b_{f}+b_{h}\right)<\left(\overline{B_{h}}+\overline{B_{f}}\right)$.

Proposition 9. If domestic investors can accommodate all of the defaultable foreign debt overhang:

a. Nash equilibrium is indeterminate (but well-behaved).

b. $b^{S M} \in\left(b_{f}-\bar{B}_{f}, \overline{B_{h}}-b_{h}\right), \quad q^{S M}=1$.

c. Both debts are repaid: $d_{h}^{S M}=0$ and $d_{f}^{S M}=0$.

Proof. See Appendix 8.4.

The result in Proposition 9 is similar to Broner et al. (2010). In their paper, before the secondary market opens the government wants to default on foreign investors (and domestic debt is zero). In the secondary market, foreigners re-trade all of their holdings to domestic investors, and the government repays in full to domestic investors. Here, 
foreign investors only re-trade the amount above their default threshold (in Broner et al. (2010) this threshold is zero), but it is enough to restore repayment on the foreign market. Domestic investors increase their holdings, but are still below the default threshold (in the cited paper this threshold is infinity) and are therefore also repaid by the government. The necessary condition for secondary markets to restore repayment on both markets when tax enforcement is costly is that the foreign debt overhang is smaller than the domestic debt accommodation space $\left(b_{f}-\bar{B}_{f}\right)<\left(\overline{B_{h}}-b_{h}\right)$.

This result affects the workings of the primary market, as it turns risky foreign debt into riskless debt. Therefore the discount price on the primary market is $q_{f}=\frac{1}{1+r}$.

The aim of this section is to show that the effects of secondary markets for government bonds are ambiguous in the situation where either domestic or foreign debt would otherwise be defaulted on. This section by no means exhausts the topic. What this section proves is that strengthening the role and efficiency of secondary markets is not a remedy that can automatically solve the sovereign risk problem. We find that the equilibria are dependent on underlying conditions, such as investors' coordination abilities and the relative size of demand and supply of bonds. Clearly more research, both empirical and theoretical, is warranted on the workings of secondary markets during sovereign risk crisis.

\section{Conclusions}

We develop a model of sovereign debt issuance on international and domestic markets, and of selective defaults. By adding domestic investors we introduces a new level of heterogeneity to a standard model of strategic sovereign default. Our model is capable of replicating selective default frequencies and business cycle statistics, and we show that including two types of investors brings the model closer to the data, as it was suggested by Aguiar and Amador (2014). Our model is a useful tool to study how the fractions of investors in public debt arise endogenously in an equilibrium, and how the composition of debt is correlated with spreads and the total debt. Our model shows that although foreign debt is more valuable and can in principle be used to smooth both output and taxation shocks, the government would still use domestic debt to smooth the domestic taxation shock. In a world with two uncorrelated

shocks (output and taxation), two types of debt (foreign and domestic) are issued, and selective defaults arise endogenously (as we observe in the data).

On the positive side, we provide a theory of the role of secondary sovereign debt markets in restoring repayment incentives. Trade in secondary markets can restore the government's repayment incentives when the supply of defaultable bonds from foreigners is low compared to demand from domestic investors. However, when the supply of defaultable bonds is high (compared to demand), then secondary markets cannot sustain repayment on both markets. If domestic investors are able to coordinate, then trade in secondary markets can be welfare-improving 
for both sides. Otherwise, if domestic investors cannot coordinate, then it is uncertain whether any trade would occur on secondary markets.

On the other hand, if foreign investors are able to coordinate then they will be willing to accept a voluntary haircut on the eve of foreign default. This would restore debt repayment on the foreign market. In the absence of coordination, foreign investors will never accept haircuts and foreign debt will be always defaulted on. In particular situations when secondary markets fail to improve the allocation, a voluntary haircut does, and vice versa. Our results shed some light on the Greek government debt crisis, when in 2012 private investors agreed to a voluntary haircut while trade in government bonds on secondary markets was negligible.

How investors' coordination may arise endogenously is an interesting and important issue for further research. However, as investors' coordination improves the allocation and welfare outcomes, we hypothesize that within a group each investor has incentives to defect on coordination and free-ride on the coordinating majority. Instances of this behavior have been seen in recent default episodes, especially prior to the 2014 Argentinian default. 


\section{References}

Aguiar, M. And M. Amador (2014): "Sovereign Debt," in Handbook of International Economics Vol 4, NorthHolland, 647-687.

Andrew Young School of Policy Studies (2010): “Andrew Young School World Tax Indicators," Accessed: June, $30,2015$.

Andritzky, J. R. (2012): "Government Bonds and their Investors," IMF Working Papers 12/158, International Monetary Fund.

Arellano, C. (2008): "Default Risk and Income Fluctuations in Emerging Economies," American Economic Review, 98, 690-712.

Broner, F., A. Martin, And J. Ventura (2010): "Sovereign Risk and Secondary Markets," American Economic Review, 100, 1523-55.

Browning, E. K. (1976): "The Marginal Cost of Public Funds," Journal of Political Economy, 84, 283-98.

Cooper, R., H. Kempf, And D. Peled (2008): "Is It Is Or Is It Ain't My Obligation? Regional Debt In A Fiscal Federation," International Economic Review, 49, 1469-1504.

Dasgupta, P. and E. Maskin (1986a): "The Existence of Equilibrium in Discontinuous Economic Games, I:

Theory," Review of Economic Studies, 53, 1-26.

Dasgupta, P. and E. Maskin (1986b): "The Existence of Equilibrium in Discontinuous Economic Games, II: Applications," Review of Economic Studies, 53, 27-41.

Dell'Erba, S., R. Hausmann, and U. Panizza (2013): "Debt Levels, Debt Composition, and Sovereign Spreads in Emerging and Advanced Economies," Oxford Review of Economic Policy, 29, 518-547.

D'Erasmo, P. and E. G. Mendoza (2013): "Distributional Incentives in an Equilibrium Model of Domestic Sovereign Default," NBER Working Papers 19477, National Bureau of Economic Research, Inc.

Eaton, J. And M. Gersovitz (1981): "Debt with Potential Repudiation: Theoretical and Empirical Analysis," Review of Economic Studies, 48, 289-309.

Erce, A. (2012): "Selective Sovereign Defaults," Tech. rep.

Feenstra, R. C., R. Inklaar, And M. P. Timmer (2015): "The Next Generation of the Penn World Table," American Economic Review, forthcoming. 
Feldstein, M. (1999): "Tax Avoidance And The Deadweight Loss Of The Income Tax," The Review of Economics and Statistics, 81, 674-680.

Gelos, R. G., R. Sahay, And G. Sandleris (2011): "Sovereign borrowing by developing countries: What determines market access?" Journal of International Economics, 83, 243-254.

Harberger, A. (1964): "Taxation, Resource Allocation, and Welfare," in The Role of Direct and Indirect Taxes in the Federal Reserve System, National Bureau of Economic Research, Inc, NBER Chapters, 25-80.

KPMG (2015): "Tax Rates Online," Accessed: June, 30, 2015.

Merler, S. And J. Pisani-Ferry (2012): "Who's afraid of sovereign bonds?” Policy Contributions 695, Bruegel.

Office of Tax Policy Research (2015): "World Tax Database," Accessed: June, 30, 2015.

Oxford University Centre for Business Taxation (2015): "CBT Tax Database," Accessed: June, 30, 2015.

PanizZa, U. (2008): "Domestic And External Public Debt In Developing Countries," Tech. rep.

Pouzo, D. And I. Presno (2014): "Optimal Taxation with Endogenous Default under Incomplete Markets," Working paper.

Prichard, W., A. Cobham, And A. Goodall (2014): "The ICTD Government Revenue Dataset," .

Reinhart, C. M. and K. S. Rogoff (2011a): "The Forgotten History of Domestic Debt," Economic Journal, 121, 319-350.

Reinhart, C. M. And K. S. Rogoff (2011b): "From Financial Crash to Debt Crisis," American Economic Review, 101, 1676-1706.

Stuart, C. E. (1984): "Welfare Costs per Dollar of Additional Tax Revenue in the United States," American Economic Review, 74, 352-62.

Vasishtha, G. (2010): "Domestic versus External Borrowing and Fiscal Policy in Emerging Markets," Review of International Economics, 18, 1058-1074. 


\section{Appendix}

\subsection{Two Period Model}

\section{A. Algorithm}

We solve for the government's optimal domestic and foreign debt policies in the first period following these steps:

1. Assuming that (17) and (18) are satisfied in the second period, we write the government's problem as (19).

2. The solution to the problem is then a set of two first-order conditions (22) and (23) and pricing rules (20) and (21).

3. We pick a set of parameters and solve (19) numerically.

4. We confirm that the resulting policy functions $b_{f}, b_{h}$ and equilibrium prices $q_{f}, q_{h}$ satisfy conditions (17)-(18), and therefore that expectations in (19) are consistent in equilibrium.

5. We vary one parameter at a time within a range where (17)-(18) are satisfied to derive comparative statics.

\section{B. Parametrization}

\begin{tabular}{|c|c|c|c|}
\hline Parameter & Value & Range & Description \\
\hline$y$ & 1 & & Output today / High output tomorrow \\
\hline$\sigma$ & 1 & & Risk aversion of Home agents \\
\hline$\Pi_{y}$ & 0.72 & {$[0.5,1]$} & Probability of high output \\
\hline$\Pi_{\tau}$ & 0.8 & {$[0.5,1]$} & Probability of low tax distortion \\
\hline$g$ & 0.7 & {$[0.5,0.8]$} & Gov. expenditure \\
\hline$y_{L}$ & 0.5 & {$[0.10 .7]$} & Low output \\
\hline$\tau_{1}$ & 0.1 & {$[0,0.2]$} & Tax distortions today \\
\hline$\tau_{H}$ & 0.15 & {$[0.1,0.2]$} & Tax distortions tomorrow (high) \\
\hline$\tau_{L}$ & 0.05 & {$[0,0.15]$} & Tax distortions tomorrow (low) \\
\hline$\delta_{f}$ & 0.65 & {$[0.42,0.87]$} & Output cost of Foreign default \\
\hline$\delta_{h}$ & 0.05 & {$[0,0.15]$} & Output cost of Home default \\
\hline$r$ & 0.00 & & Risk-free interest rate \\
\hline
\end{tabular}




\subsection{Solution Algorithm}

1. Guess price schedules $p_{f}^{0}$ and $p_{h}^{0}$.

2. Calculate consumption in autarky $c^{a u t}$ and value of permanent autarky $V^{\text {aut }}$.

3. Guess four value functions $V^{00}, V^{0 f d}, V^{0 h d}$ and $V^{0 t d}$ using $V^{a u t}$.

4. Calculate optimal policies $b_{f}$ and $b_{h}$ in repayment given $V^{00}$ as continuation value and prices.

5. Calculate value of repayment $V^{r}$ given optimal policies and continuation value.

6. Repeat steps 4 and 5 for foreign default and domestic default to obtain $V^{1 f d}$ and $V^{1 h d}$.

7. Calculate value of total default $V^{1 t d}$ given $V^{1 f d}$ and $V^{1 h d}$ and $V^{00}$.

8. Derive optimal default policies $d$ comparing four value functions $V^{r}, V^{1 f d} V^{1 h d} V^{1 t d}$ at each grid point $\left\{b_{f}, b_{h}, y, \tau\right\}$.

9. Derive new value function $V^{10}$ as maximum of four value functions used in previous step at each grid point.

10. Substitute $V^{00}=V^{10}$.

11. Repeat steps 3-9 until convergence in value function.

12. Given optimal default policies $d$ calculate prices of foreign and domestic debt $q_{f}^{1}$ and $q_{h}^{1}$ at each grid point using pricing rules (31) and (30).

13. Update prices $q_{f}^{0}=\alpha^{f} q_{f}^{0}+\left(1-\alpha^{f}\right) q_{f}^{1}$ and $q_{h}^{0}=\alpha^{h} q_{h}^{0}+\left(1-\alpha^{h}\right) q_{h}^{1}$.

14. Repeat steps 1-13 until convergence in prices. 


\subsection{Two Period Model. Graphical Solutions}
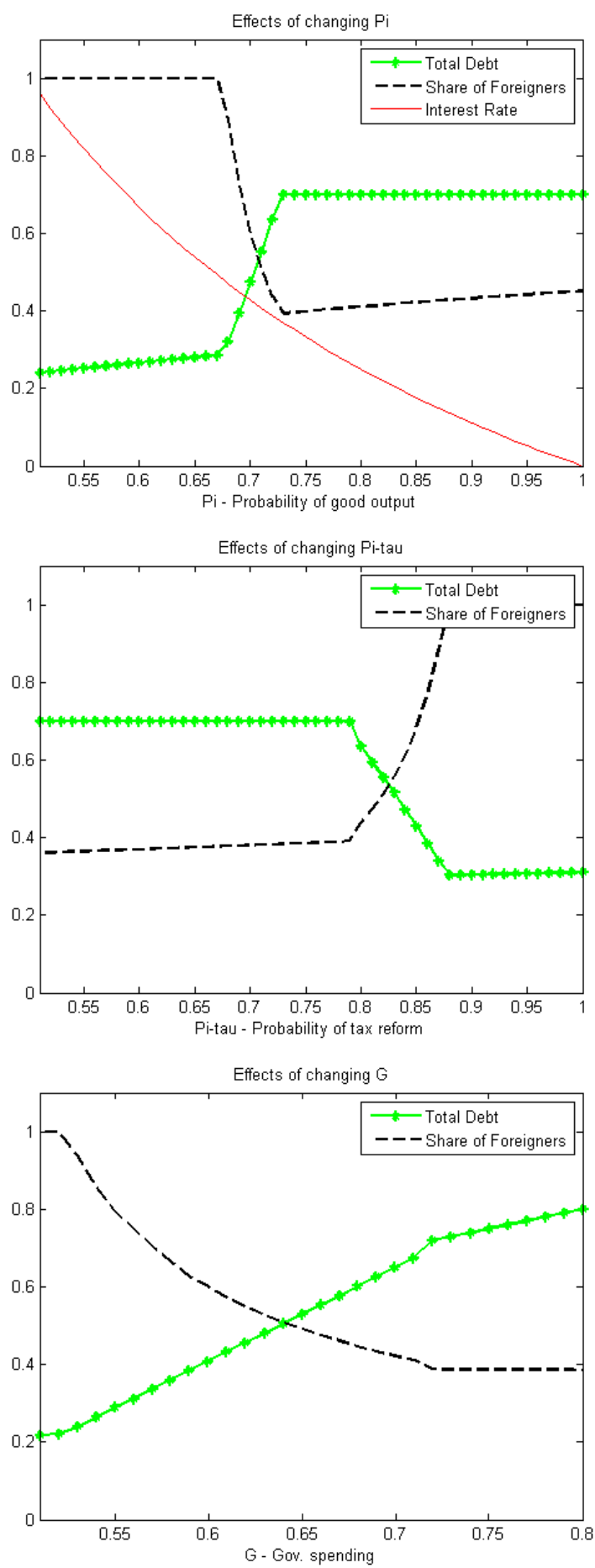

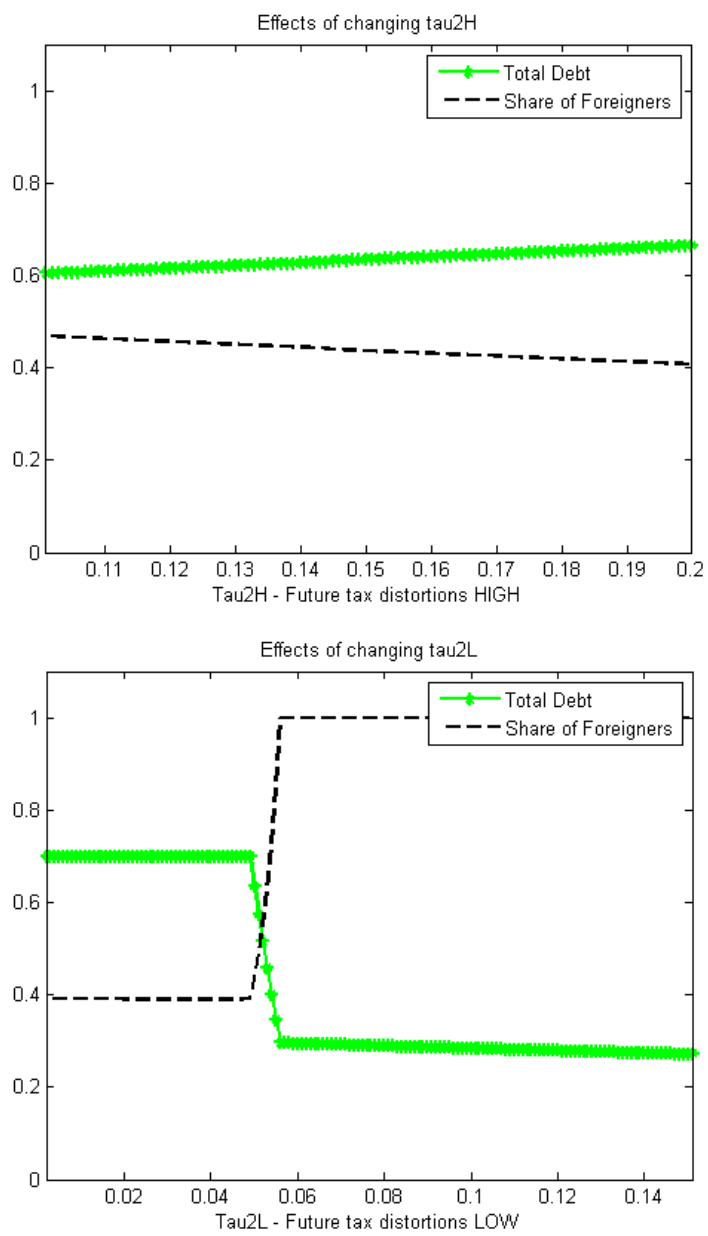

Effects of changing $Y_{L}$

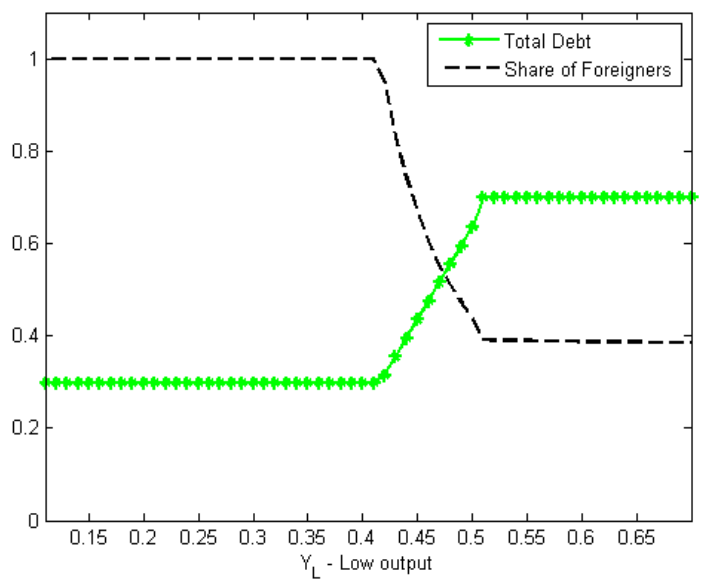




\subsection{Secondary Markets. Proofs of Propositions}

Proof of Proposition 4.

We study situation B depicted in the Figure 2: outcome on the primary market yields foreign default (FD) and domestic repayment (DR). Before engaging in the trade on the secondary markets, both types of investors (domestic and foreign) need to form expectations about the government's decision to default. There are three possible outcomes: foreign default and domestic repayment (FD, DR); foreign repayment and domestic default (FR, DD) and total default (FD, DD). The repayment of both debts is ruled out by the fact that total debt is greater than the total default limit $b_{f}+b_{h}>\bar{B}_{h}+\bar{B}_{f}$.

There are two thresholds related to the volume traded in the secondary markets $b^{S M}$. If the traded volume lies below lower threshold $b^{S M} \leq \overline{B_{h}}-b_{h}$, domestic debt is repaid, while foreign debt is defaulted. If the traded volume is between lower and upper threshold $\bar{B}_{h}-b_{h}<b^{S M}<b_{f}-\bar{B}_{f}-b_{h}$, both debts are defaulted; if the traded volume lies above upper threshold $b^{S M} \geq \overline{B_{h}}-b_{h}$ domestic debt is defaulted, while foreign debt is repaid.

We draw three best-response correspondences: for foreign investors (the solid red line), for domestic investors (the dashed blue line) and for the government in a single graph with the amount of trade $b^{S M}$ on the horizontal axis and the price $q^{S M}$ of debt on the vertical axis. The brown shaded area represents the area of trade, in which the expectations are consistent with the government decision: in the first panel the shaded area represents the amounts traded for which the government will choose (FD, DR), in the second panel the shaded area represents the amounts traded for which the government will choose (FD, DD) and in the third panel shaded area represents the amouts traded for which the government will choose (FR, DD). A crossing of the two best best response correspondences, which lies within shaded area represents a Nash equilibrium in pure strategies (secondary markets clear and expectations of investors are consistent with the government's decision). As can be seen in Figure 10, the only outcome that is consistent is the total default. In this case the price on the secondary markets is zero, but the amount of trade is undetermined.

Proof of Proposition 5.

We follow a similar procedure to the Proof of Proposition 4. However, there is one substantial difference. If domestic investors are $\epsilon$-size, they internalize the effects of their actions on the government's decision. Since $b_{f}+b_{h}>\bar{B}_{h}+\bar{B}_{f}$ at least one type of debt will be defaulted. The outcome on the primary market yields domestic repayment. Since each domestic investor is $\epsilon$-size, she will never demand any amount that exceeds domestic default threshold, as this will unambigously decrease her payoff. Hence $b_{h}^{S M} \leq \bar{B}_{h}-b_{h}$. In this, domestic investors can effectively insure domestic repayment.

Therefore, the only possible outcome that is consistent in equilibrium is foreign default and domestic repayment (FD,DR). Contrary to the Proof of Proposition 4 we can narrow our considerations and study only one game when 
Figure 10: Best response functions for infinitesimal investors

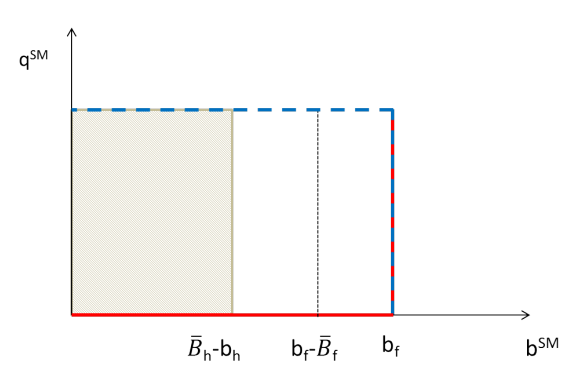

(a) (FD, DR)

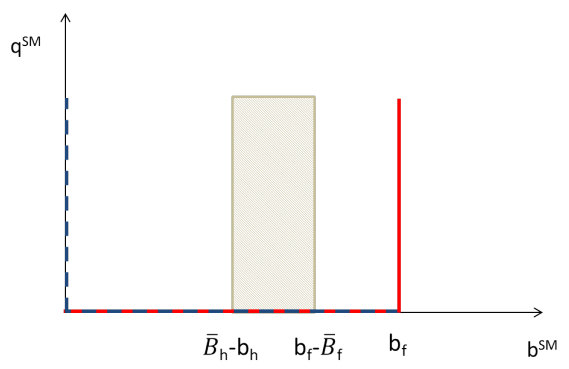

(b) $(\mathrm{FD}, \mathrm{DD})$

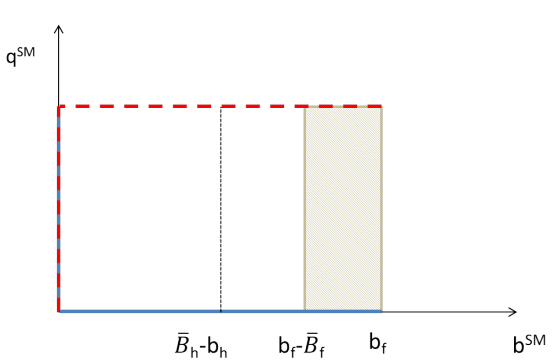

(c) $(\mathrm{FR}, \mathrm{DD})$

both types of investors expect (FD, DR). The best response function of single foreign investor depends on whether she is: (a) zero-size, (b) $\epsilon$-size and expecting domestic investors to be zero-size (uninformed foreign investor) or (c) $\epsilon$-size and knows that domestic investors are $\epsilon$-size (informed foreign investor). In Figure 11 we draw best response functions for the three cases.

If foreign investors are infinitesimal (panel (a)) they do not coordinate and each of them wants to sell all of her debt holdings $\left(b_{f}\right)$ as long as price on the secondary markets is positive. Hence, there exist a unique equilibrium where at zero price $q^{S M}$ the maximum possible amount of debt $b^{S M}=\bar{B}_{h}-b_{h}$, that insures domestic repayment, is traded. Secondly, when foreign investors are $\epsilon$-size but uninformed (panel (b)), they coordinate their supply on the amount that exceeds $b_{f}-\overline{B_{h}}$ (that will insure they are repaid by the government in the primary market) as long as price is positive. Similarly, there exist a unique equilibrium where at zero price $q^{S M}$ the maximum possible amount of debt $b^{S M}=\bar{B}_{h}-b_{h}$, that insures domestic repayment, is traded. Thirdly, if foreign investors are $\epsilon$-size and informed that domestic investors coordinate (panel (c)), the traded amount remains $b^{S M}=\bar{B}_{h}-b_{h}$, but the price is undetermined $q^{S M} \in[0,1]$.

Proof of Proposition 6.

We consider the opposite case to the Proof of Proposition 5. Foreign investors are $\epsilon$-size, they internalize the effect of their actions on the government decision, while domestic investors are infinitesimal. Since $b_{f}+b_{h}>\overline{B_{h}}+\overline{B_{f}}$, at least the one type of debt will be defaulted by the government. Hence, foreign investors coordinate to insure foreign repayment (FR). The only possible outcome that is consistent in equilibrium is foreign repayment and domestic default (FR,DD). In Figure 12 we draw the best response functions for this case. There exists a unique equilibrium, where at zero price $q^{S M}$ the minimum possible amount $b^{S M}=b_{f}-\bar{B}_{f}$, that insures foreign repayment, is traded. 
Figure 11: Best response functions for $\epsilon$-size domestic investors

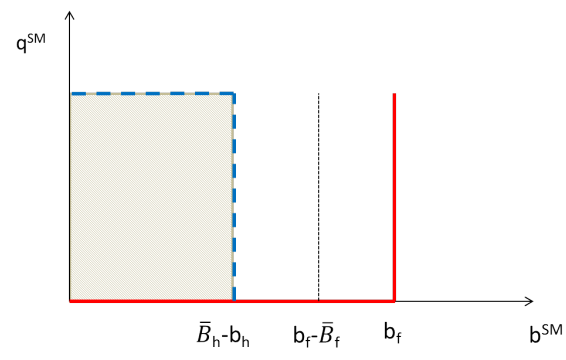

(a) Infinitesimal foreign investors

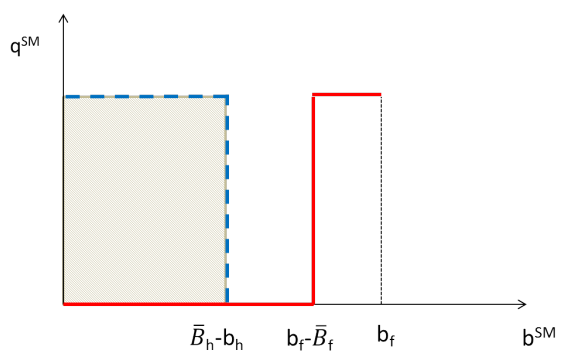

(b) Uninformed $\epsilon$-size foreign investors

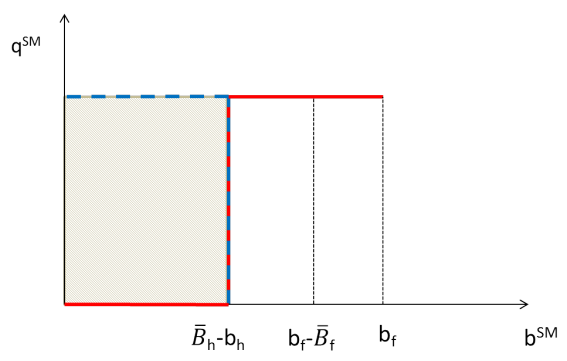

(c) Informed $\epsilon$-size foreign investors

Figure 12: Best response functions for $\epsilon$-size foreign and infinitesimal domestic investors

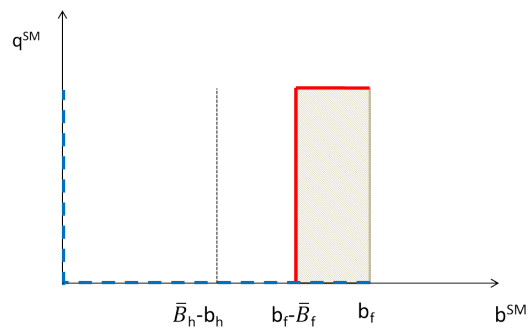

Proof of Proposition 7 and 8.

We consider an alternative way (compared to Proposition 6) to bring foreign debt $b_{f}$ down (weakly) below its default threshold $\bar{B}_{f}$. Foreign investors are $\epsilon$-size, they internalize the effect of their actions on the government decision. As shown in the previous proposition, engaging in the secondary market does not bring direct benefit for foreign investors, but it might restore foreign repayment under very specific circumstances. The option of free disposal plays a similar role. It does not bring a direct benefit, but it insures foreign repayment as long as foreign investors can coordinate on the minimum amount of a haircut $b_{f}-\bar{B}_{f}$. The free disposal requires only the coordination between foreign investors.

Proof of Proposition 9.

We study situation B depicted in the Figure 2: outcome on the primary market yields foreign default (FD) and domestic repayment (DR). Before engaging in the trade on the secondary markets, both types of investors (domestic and foreign) need to form expectations about the government's decision to default. There are three possible outcomes: foreign default and domestic repayment (FD, DR); foreign repayment and domestic default (FR, DD) and total default (FD, DD). The repayment of both debts is ruled out by the fact that total debt is 
greater than the total default limit $b_{f}+b_{h}>\bar{B}_{h}+\bar{B}_{f}$.

There are two thresholds related to the volume traded in the secondary markets $b^{S M}$. If the traded volume lies below lower threshold $b^{S M} \leq \bar{B}_{h}-b_{h}$, domestic debt is repaid, while foreign debt is defaulted. If the traded volume is between lower and upper threshold $\bar{B}_{h}-b_{h}<b^{S M}<b_{f}-\bar{B}_{f}-b_{h}$, both debts are defaulted; if the traded volume lies above upper threshold $b^{S M} \geq \overline{B_{h}}-b_{h}$ domestic debt is defaulted, while foreign debt is repaid.

We draw three best-response correspondences: for foreign investors (the solid red line), for domestic investors (the dashed blue line) and for the government in a single graph with the amount of trade $b^{S M}$ on the horizontal axis and the price $q^{S M}$ of debt on the vertical axis. The brown shaded area represents the area of trade, in which the expectations are consistent with the government decision. A crossing of the two best best response correspondences, which lies within shaded area represents a Nash equilibrium in pure strategies (secondary markets clear and expectations of investors are consistent with the government's decision).

In Figure 13 we draw best response correspondences for the case of infinitesimal foreign and inifinitesimal domestic investors. Only in panel (b), depicting the case when both types of investors expect domestic repayment and foreign repayment (FR, DR), best correspondences cross in the shaded area, which means that expectations are consistent in equilibrium. In a unique equilibrium both debt are repaind, the volume volume is however undetermined $b^{S M} \in\left(b_{f}-\bar{B}_{f}, \overline{B_{h}}-b_{h}\right)$ and the price is equal to one $q^{S M}=1$.

Figure 13: Best response functions for infinitesimal foreign and infinitesimal domestic investors

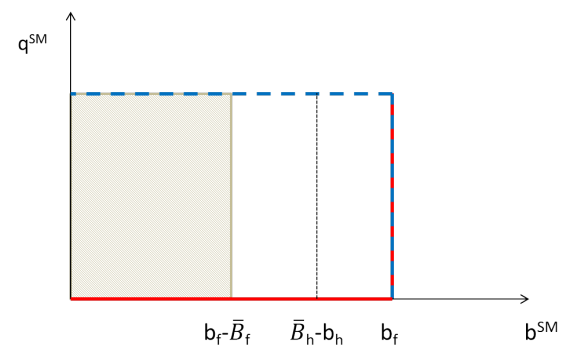

(a) $(\mathrm{FD}, \mathrm{DR})$

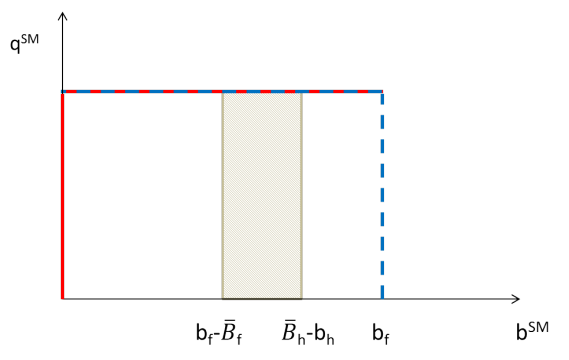

(b) $(\mathrm{FR}, \mathrm{DR})$

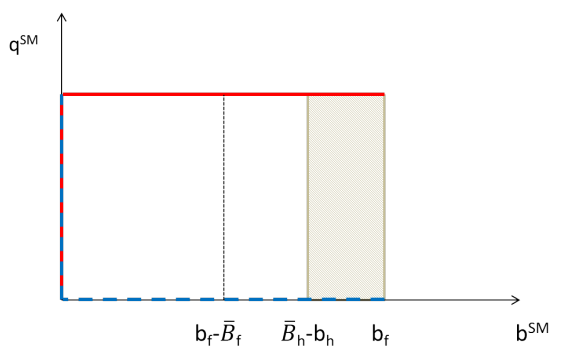

(c) $(\mathrm{FR}, \mathrm{DD})$

Since $b_{f}+b_{h}<\bar{B}_{h}+\bar{B}_{f}$, both debts can be potentially repaid, even without coordination. Coordination of foreign/domestic investors reinforces foreign/domestic repayment. Interestingly, coordination does not change the outcome. In Figure 14 we plot best response correpospondences of domestic and foreign investors together with government's optimal default decision in single graphs for three remaining cases: (a) $\epsilon$-size foreign and infinitesimal domestic investors, (b) infinitesimal foreign and $\epsilon$-size domestic investors and (c) $\epsilon$-size foreign and $\epsilon$-size domestic investors. For each case best response correspondences differ slightly, but an equilibrium is the same across all three cases.

Finally, let us consider two other cases, in which one class of investors consists of $\epsilon$-size agents, whereas the other 
Figure 14: Best response functions for $\epsilon$-size investors

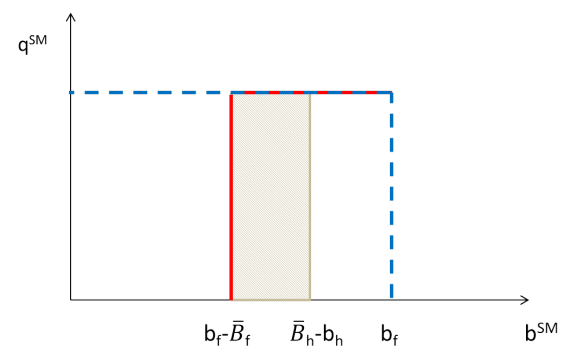

(a) $\epsilon$-size foreign and

infinitesimal domestic investors

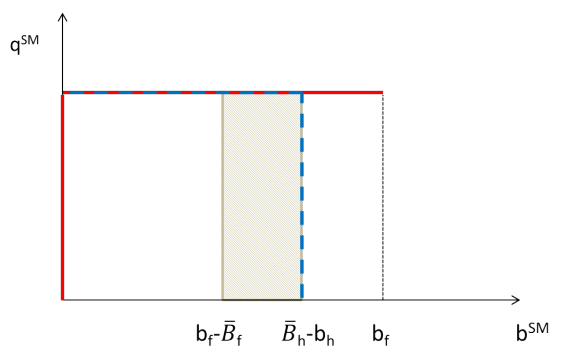

(b) infinitesimal foreign and

$\epsilon$-size domestic investors

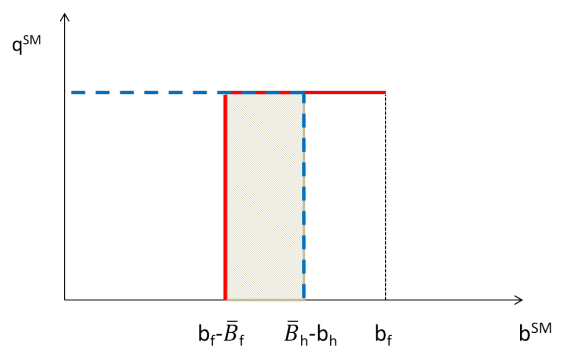

(c) $\epsilon$-size foreign and

$\epsilon$-size domestic investors

of infinitesimal agents. As shown in Propositions 5 and 6 the class that consists of agents of $\epsilon$-size has an advantage, as they can coordinate on their most favourable outcome. We want to check, whether in the case studied here, the side with an advantage can coordinate on their most favourable outcome.

Figure 15: Best response functions with one-sided advantage

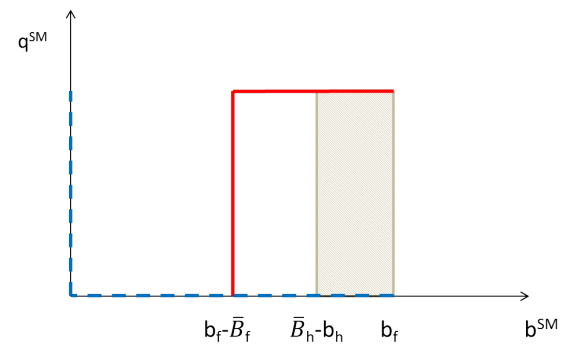

(a) $\epsilon$-size foreign and

infinitesimal domestic investors

(FR, DD)

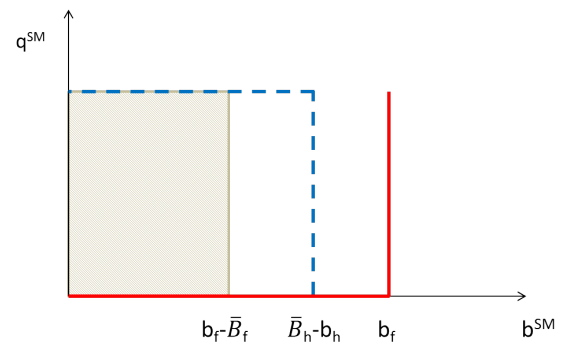

(b) infinitesimal foreign and $\epsilon$-size domestic investors

(FD, DR)

In panel (a) of Figure 15 we plot best response correspondences when foreign investors are $\epsilon$-size (have an advantage) and domestic investors are infinitesimal. Both investors expect government to default on domestic debt and repay the foreign debt (FR, DD). Even though foreign investors might potentially coordinate on any level of debt, for example $\overline{B_{h}}-b_{h}$, they would not do so. This volume and the price $q^{S M}=0$ cannot be an equilibrium, because there is a profitable deviation for each foreign investors to reduce her traded volume down to $b_{f}-\bar{B}_{f}$ and therefore to secure domestic repayment. Foreign repayment and domestic default (FR, DD) cannot be sustained as an equilibrium.

In panel (b) of Figure 15 we plot best response correspondences when domestic investors are $\epsilon$-size (have an 
advantage) and foreign investors are infinitesimal. Both investors expect government to default on foreign debt and repay the domestic debt $(\mathrm{FD}, \mathrm{DR})$. Even though domestic investors might potentially coordinate on any level of debt, for example $b_{f}-\bar{B}_{f}$, they would not do so. This volume and the price $q^{S M}=0$ cannot be an equilibrium, because there is a profitable deviation for each domestic investors to always increase the traded volume, up until the point, where it meets supply from foreign investors if $\bar{B}_{h}-b_{h}$ and therefore to secure foreign repayment. Foreign default and domestic repayment (FD, DR) cannot be sustained as an equilibrium. 